\title{
Fossil Energy Program Progress Report for January 1978
}

\section{OAK RIDGE NATIONAL LABORATORY}

OPERATED BY UNION CARBIDE CORPORATION · FOR THE DEPARTMENT OF ENERGY 


\section{DISCLAIMER}

This report was prepared as an account of work sponsored by an agency of the United States Government. Neither the United States Government nor any agency Thereof, nor any of their employees, makes any warranty, express or implied, or assumes any legal liability or responsibility for the accuracy, completeness, or usefulness of any information, apparatus, product, or process disclosed, or represents that its use would not infringe privately owned rights. Reference herein to any specific commercial product, process, or service by trade name, trademark, manufacturer, or otherwise does not necessarily constitute or imply its endorsement, recommendation, or favoring by the United States Government or any agency thereof. The views and opinions of authors expressed herein do not necessarily state or reflect those of the United States Government or any agency thereof. 


\section{DISCLAIMER}

Portions of this document may be illegible in electronic image products. Images are produced from the best available original document. 


\section{Printed in the United S'tates of America. Available from National Technical Information Service \\ U.S. Department of Commerce \\ 5285 Port Royal Road, Springfield, Virginia 22161 \\ Price: Printed Copy $\$ 5.25$; Microfiche $\$ 3.00$}

This report was prepared as an account of work sponsored by an agency of the United States Government. Neither the United States Government nor any agency thereof, nor any of their employees, contractors, subcontractors, or their employees, makes any warranty, express or implied, nor assumes any legal liability or responsibility for any third party's use or the results of such use of any information, apparatus, product or process disclosed in this report, nor represents that its use by such third party would not-infringe privately owned rights. 
Contract No. W-7405-eng-26

Central Management Office

FOSSIL ENERGY PROGRAM

PROGRESS REPORT FOR JANUARY 1978

Date Published - March 1978

Tils ieport was prepared as an accuint of work

sponsored by the United States Govemment. Neither the

Unitad States nor the United States Department of

Energy, nor any of their employees, nor any of their

contractors, subcontractors, or their employees, makes

any warranty, express or implied, oz assumes any legal

liability or responsibility for the accuracy, completeness

or use fulness of any information, appaiatus, product on

orocess disclosed, or represents that its use would not

infringe privately owried nghis.

i

renche

OAK RIDGE NATIONAL LABORATORY

Oak Ridge, Tenncesee 37830

operated by

UNION CARBIDE CORPORATION

for the

DEPARTMENT OF ENERGY 
Form ERDA 426

$(2 \pi 5)$

ERDAM 3201
U.S. ENERGY RESEARCH \& DEVELOPMENT ADMINISTRATION

MAJOR CONTRACTOR'S RECOMMENDATION FOR ' DISPOSITION OF SCIENTIFIC AND TECHNICAL DOCUMENT

* See Instructions on Reverse

1. ERDA Report No. ORNL/TM-6274

2. Subject Category No.
3. Title Fossil Energy Program Progress Report for January 1978. Authors: L. E. McNeese, et al.

4. Type of Document (" $X$ " one)

[X] Scientific and Technical Report

$\square$ b. Conference paper:

Title of conference

Date of conference

Exact location of conference

c. Other (Specify, Thesis, Translation, etc.)*

5. Copies Transmitted (" $X$ " one or more)

$\square$ a. Copies being transmitted for standard distribution by ERDA-TIC.

$\square$ b. Copies being transmitted for special distribution per attached complete address list.*.

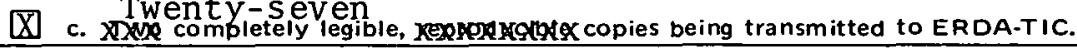

6. Recommended Distribution (" $X$ " one)

\. Normal handling (after Patent clearance): no restraints on distribution except as may be required by the security classification.

$\square$ b. Make available only to U.S. Government agencies and their contractors.

$\square$ c. Make available only within ERDA and to ERDA contractors.

$\square$ d. Make available only within ERDA.

$\square$ e. Make available only to those listed in item 12 below.

$\square$ f. Other (Sneclfy)*

7. Recommended Announcement (" $X$ " one)

DX a. Normal procedure may be followed.*

$\square$ b. Recommend following announcement limitations:

8. Reason for Restrictions Recommended in 6 or 7 above.

$\square$ a. Preliminary information.

$\square$ b. Prepared primarlly roi internal usc.

$\square$ c. Other (Explain)

9. Patent Clearance (" $X$ " one)

a. ERDA patent clearance has been granted-by responsible ERDA patent group.

$\square$ b. Document has been sent to responsible ERUA patent group for clearance.

10. National Security Information (For classified document only; " $X$ " one)

$\square$ a. Document does contain national security information other than restricted data.

$\square$ b. Document does not contain national security information other than restricted data.

11. Copy Reproduction and Distribution
a. Total number of copies reproduced
224
b. Number of copies distributed outside originating organization
112

12. Additional Information or Remarks (Continue on separate sheet, if necessary)

13. Submitted by (Name and Position) (Please print or type)*

P. S. Baker, Classification Officer

14. Organization

Oak Ridge National Laboratory

15. Signature 00 \&

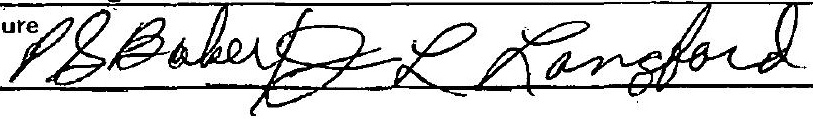

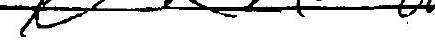

16. Date $30-20$ 


\section{INSTRUCTIONSS}

Who uses this, Form: All ERDA contractors except those specifically instructed by their ERDA contract administrator to use the shorter Form ERDA-427.

When to Use: Submit one copy of this Form with each document which is sent to ERDA's Techncial Information Center (TIC) in accordance with the requirements of ERDA Manual Chapter 3201.

Where to send: Forward this Form and the document(s) to:

$$
\begin{aligned}
& \text { USERDA-TIC } \\
& \text { P.O. Box } 62 \\
& \text { Oak Ridge, TN } 37830
\end{aligned}
$$

\section{Item instructions:}

1terin 1. The first element in the number shall be an ERDAapproved code to be determined as follows: (a) The responsible field office may request TIC approval of a unique code for a contractor, e.g., BNL, BMI, 1.INL, elc:; (b) Á progirảm division may request TIC approval of a unique code for a program or series of reports, e.g., PNE, VUF, etc.; (c) An operations office may instruct a contractor to use the code approved for the operations officc, i.e., COO, ORO, IDO, SRO, SAN, ALO, RLO, NVO; and (d) Program divisions shall use the code ERDA for reports which they themselves prepare unless there is reason to use some other approved code.

The code shall be followed by a sequential number, or by a contract number plus a sequential number, as follows: (a) Contractors or programs with unique codes may complete the report number by adding a sequential number to thc code, e.g., HNL-101, HNL-102, etc.; or PNE-1, PNE-2, etc.; or they may add the identifying portion of the contract number and a sequential numbcr, e.g., $A B C-2105-1$, $A B C-2105-2$, elc; (b) Contractors using the operations office code shall complete the report number by adding the identifying portion of the contract number and a sequential number, e.g., COO-2200-1, COO-2200-2, etc.; (c) Subcontractor reports shall be identified with the code used by the prime contractor; and (d) Program divisions using the ERDA code shall complete the report number by adding a sequential number which they request from the Library Branch, Division of Administrative Services.

Item 2. Insert the appropriate subject category from TID-4500 ("Standard Distribution for Unclassified Scientific and Technical Keports") or M-3679 ("Standard Distribution for Classified Scientific und Techunical Reports") f'or both classified and unclussified documents, whether or not printed for siandard distribution.

Item 3. Give title exactly as on the document itself unless title is classified. In that case. omit title and state "classified title" in the space for item 3.

Item 4. If box $\mathrm{c}$ is checked. indicate type of item being sent, e.g., thesis. translation. etc.

Item 5. a. If box a is checked, the number of copies specified for the appropriate category or categories in M-3679 or TID-4500 shall be forwarded to TIC for distribution.

b. If box $b$ is checked, complete address list must be provided TIC. c. If box c is checked, at least one copy shall be original ribbon or offset and be completely legible. A clear carbon copy is acceptable as a second reproducible copy.

Item 6. If box a is checked for an unclassified document, it may be distributed by TIC (after patent clearance) to addressees listed in TID-4500 for the appropriate subject category, to libraries in the U.S. and abroad, which through purchase of microfiche maintain collections of ERDA reports, and to the National Technical Information Service for sale to the public.

If box a is checked for a classlfied document, it may be distributed by TIC to addressees listed in M-3679 for the appioprlate subject category.

If a box other than a is checked, the recommended limitation will be followed unless TIC receives other instructions from the responsiblo ERDA program division.

Box $f$ may be checked in order to specify special instructions, such as "Make available only as specifically approved by the program division," etc.

Item 7: a. Announcement procedures are normally determined by the distribution that is to be given a document. If box $a$ in item 6 is checked for an unclassified document, it will normally be listed in the weekly "Accessions of Unlimited Distribution Reports by TIC" (TID-4401) and may be abstracted in "Nuclear Science Abstracts" (NSA).

A classified document, or an unclassified document for which box $b, c, d, e$, or $f$, in item 6 is checked, may be cited with appropriate subject index tcrms in "Abstracts of Limited Distribution Reports" (ALDR).

b. If the normal announcement procedures described in $7 \mathrm{a}$ are not appropriate check $7 \mathrm{~b}$ and indicate recommended announcement limitations.

Item 8 . If a box other than a is checked in item 6 , or if $7 \mathrm{~b}$ is checked, state reason. for the recummended restriction, e.g:; "prcliminary information," "prepared primarily for internal use," etc.

Item 9. It is assumed that there is no objection to publication from the standpoint of the originating organization's patent interest. Otherwise explain in item 12.

Item 10. If box a is checked, document cannot be made available to Access Permit holders (Code of Federal Regulations, 10 CFR, Part 25, subpart 25.6); if box $b$ is checked, TIC will determine whether or not to make it available to them.

Item 11. Self explanatory.

Item 12. Use this space if necessary to expand on answers given above, e.g., item $6 \mathrm{f}$ and item 8 .

Item 13. Linter name of person to whom inquiries concerning the recommendations on this form may be addressed.

Item 14-16. Self explanatory. 


\section{CONTENTS}

1. SUMMARY . . . . . . . . . . . . . . . . . . . . 1

2. COAL CONVERSION PROCESS DEVELOPMENT . . . . . . . . . . . . . 4

2.1 Hydrocarbonization Research . . . . . . . . . . . . . . 4

2.2 Experimental Engineering Support of In Situ Gasification Processes . . . . . . . . . . . 8

3. MATERIALS ENGINEERING . . . . . . . . . . . . . . . 16

3.1 Pressure Vessel and Piping Materials . . . . . . . . 16

3.2 Inspection Techniques for Wear- and Process-Resistant Coatings . . . . . . . . . . . 17

3.3 Fossil Energy Welding and Cladding Program . . . . . . . 18

3.4 Fireside Corrosion of Atmospheric Fluidized Bed Combustor Tubes . . . ... . . . . . . . . . . . 19

3.5 Failure Analysis and Prevention . . . . . . . . . . 21

3.6 References for Section 3 . . . . . . . . . . . . . 25

4. ALKALI METAL VAPOR TOPPING CYCLE . . . . . . . . . . . . . . 26

4.1 Gas-Fired Potassium Boiler . . . . . . . . . . . . 26

5. COAL EQUIPMENT TEST PROGRAM . . . . . . . . . . . . . . 28

5.1 Critical Equipment for Demonstration Plants . . . . . . . 28

5.2 Coal Feeder Test Program . . . . . . . . . . . . . . . 29

5.3 Survey of Industrial Capability for Coal Handling Equipment . . . . . . . . . . 29

6. ATMOSPHERIC FLUIDIZED BED COAL COMBUSTOR FOR

COGENERATION (AFB CCC) . . . . . . . . . . . . . . . . . . . 30

6.1 System Design and Assessment . . . . . . . . . . . . . 30

6.2 Supplemental Studies . . . . . . . . . . . . . . 30

7. ENGINEERING STUDIES AND TECHNICAL SUPPORT . . . . . . . . . . . 31

7.1 Process Modeling . . . . . . . . . . . . . . . . . 31

7.2 Synthetic Fuels Process Research Digest . . . . . . . . . 32

7.3 Survey of Industrial Coal Conversion Equipment Capabilities . . . . . . . . . . . . . . . 33

7.4 Flash Hydropyrolysis . . . . . . . . . . . . . . 34

7.5 Hot Gas Purification Processes . . . . . . . . . . . . 34

7.6 State-of-the-Art Review of Heat Recovery Processes . . . 35

7.7 Assessment of a Moving Bed System for Cleanup of Raw Gasifier Gas . . . . . . . . . . . . . . . . 35

7.8 Technical/Economic Assessment of Hydrogen Production by the Steam/Molten Iron Process . . . . . . . . . . . 36

7.9 A Study of Effluent Control Technologies for Hydrocarbon and Carbon Monoxide Emissions from Coal Conversion Plants 
7.10 Environmental Controls for Low-Btu Gasification . . . . . 37

7.11 Support of the office of Initial Operations (OIO) . . . . 38

8. PROCESS AND PROGRAM ANALYSIS . . . . . . . . . . . . . . . 40

8.1 Low-Btu Coal Gasification . . . . . . . . . . . . . . . . . 40

8.2 Direct Combustion . . . . . . . . . . . . . . . . . 40

8.3 Advanced Power Conversion Systems . . . . . . . . . . 43

8.4 In Situ Coal Gasification . . . . . . . . . . . . . 43

8.5 Coal Beneficiation . . . . . . . . . . . . . . 44

8.6 Gas Cleanup Studies. . . . . . . . . . . . . 45

8.7 HYGAS Modeling . . . . . . . . . . . . . . . . 45

8.8 Liquifaction .. . . . . . . . . . . . . . 46

8.9 High Btu Gas .. .................... 47

8.10 Comparative Cost Estimates of Five Coal Utilization

Processes . . . . . . . . . . . . . . . . . . 48

8.11 References for Section 8 . . . . . . . . . . . . 49

9. FOSSIL ENERGY ENVIRONMENTAL PROJECT . . . . . . . . . . . . . 50

9.1 Stored Solids Study . . . . . . . . . . . . . . . 50

9.2 Environmental Monitoring Handbook . . . . . . . . . 50

9.3 Technical Assistance .. . . . . . . . . . . . . . 51

9.4 Carryover Activities from FY 1977 . . . . . . . . . . 51

10. MAGNETIC BENEFICIATION OF DRY PULVERIZED COAL . . . . . . . . 52

10.1 Objective . . . . . . . . . . . . . . . . . . . 52

10.2 Status Summary . . . . . . . . . . . . . 52

11. ATMOSPHERIC FLUIDIZED BED COMBUSTION DEMONSTRATION PLANT . . . 54

11.1 Demonstration Plant Management Support . . . . . . . . . . 54

11.2 Technology Assessment . . . . . . . . . . . . . 54 
ORNL/TM-5044, Progress Report for August 1974

ORNL/TM-5045, Progress Report for September 1974

ORNL/TM-5046, Progress Report for October 1974

ORNL/TM-4787, Progress Report for November 1974

ORNL/TM-4796, Progress Report for December 1974

ORNL/TM-4850, Progress Report for January 1975

ORNL/TM-4873, Progress Report for February 1975

ORNL/TM-4892, Progress Report for March 1975

ORNL/TM-4946, Progress Report for April 1975

ORNL/TM-4966, Progress Report for May 1975

ORNL/TM-5010, Progress Report for June 1975

ORNL/TM-5037, Progress Report for July 1975

ORNL/TM-5092, Progress Report for August 1975

ORNL/TM-5124, Progress Report for September 1975

ORNL/TM-5186, Progress Report for October 1975

ORNL/TM-5214, Progress Report for November 1975

ORNL/TM-5246, Progress Report for December 1975

ORNL/TM-5301, Progress Report for January 1976

ORNL/TM-5321, Progress Report for February 1976

ORNL/TM-5430, Progress Report for March 1976

ORNL/TM-5479, Progress Report for April 1976

ORNL/TM-5532, Progress Report for May 1976

ORNL/TM-5595, Progress Report for June 1976

ORNL/TM-5611, Progress Report for July 1976

ORNL/TM-5654, Progress Report for August 1976

ORNL/TM-5674, Progress Report for September 1976

ORNL/TM-5717, Progress Report for October 1976

ORNL/TM-5752, Progress Report for November 19.76

ORNL/TM-5770, Progress Report for December 1976

ORNL/TM-5819, Progress Report for January 1977

ORNL/TM-5858, Progress Report for February 1977

ORNL/TM-5883, Progress Report for March 1977

ORNL/TM-5932, Progress Report for April 1977

ORNL/TM-5980, Progress Report for May 1977

ORNL/TM-6003, Progress Report for. June 1977

ORNL/TM-6038, Progress Report for July 1977

ORNL/TM-6066, Progress Report for August 1977

ORNL/TM-6104, Progress Report for September 1977

ORNL/TM-6137, Progress Report for October 1977

ORNL/TM-6217, Trogress Report for November 1977

ORNL/TM-6262, Progress Report for December 1977 
ABSTRACT

This report - the forty second of a series - is a compendium of monthly progress reports for the ORNL research and development programs that are in support of the increased utilization of coal and other fossil fuel alternatives to oil and gas as sources of clean energy. The projects reported this month include those for coal conversion process development, materials engineering, alkali metal vapor topping cycles, a coal equipment test program, an AFB coal combustor for cogeneration (CCC), engineering and support studies, process and program assistance, environmental assessment studies, magnetic beneficiation, and AFBC demonstration plant.

\section{Summary}

\section{E. McNeese}

Highlights of our progress in January are as follows:

- Hydrocarbonization run HC-25 was completed using Wyodak coal at a lower system pressure (150 psig) than used in previous runs to obtain information on the effect of pressure on yields. The run proceeded smoothly with no interruption of feed or other difficulties. Material balance and oil yield data for run $\mathrm{HC}-24$, which was made using Illinois No. 6 coal that had been treated with $\mathrm{Na}_{2} \mathrm{CO}_{3}$, were completed.

- In support of in situ gasification, block pyrolysis experiments $\mathrm{BP}-42$ and -43 were conducted at $0.3^{\circ} \mathrm{C} / \mathrm{min}$ reaching surface temperatures of 900 and $1000^{\circ} \mathrm{C}$, respectively. These experiments are a continuation of a series of bituminous coal block pyrolysis experiments using $\mathrm{H}_{2}$ reactor purge gas.

- The toughness of $21 / 4 \mathrm{Cr}-1$ Mo in thick sections suitable for large coal conversion systems is being explored in our pressure vessel and piping materials work for material in the as-fabricated condition. Preparation of a facility for environmental exposure of materials is underway.

- Equipment modification for plasma spraying of CoCrAlY have been completed in our coatings inspection program. We are debugging the modified reflection-coil computer program for eddy current testing; our through-transmission computer program operates satisfactorily. We made two tensile crack specimens from the metallic-coated ANL (C5) specimen as an interim measure until CoCrAlY specimens became available. Closeout 
work on two cermet penetrant specimens was also performed. Construction of the scanning thermometric probe for unbond detection in CoCrAlY coated specimens has begun.

- In our welding and cladding program, a range of welding parameters has been found for depositing type $320 \mathrm{cb}$ stainless steel on carbon steel clad with Inconel 82 that produces no cracking on the finished surface. Some internal fissuring was found metallographically; the extent of internal fissuring appears to be related to the amount of nickel dilution in successive passes. We are making deposits on $21 / 4 \mathrm{Cr}-1$ Mo substrate material.

- The corrosion data from our fireside conversion tests for types 304,316 , and 310 stalnlcss steel, Alloy 600, and A1luy 800 exposed to the Fluidyne atmospheric fluidized bed combustor for $500 \mathrm{hr}$ and $1500 \mathrm{hr}$ are summarized in this report. High-temperature specimens for a $3000 \mathrm{hr}$ run have been prepared.

- A failure analysis of heat exchanger tubes from the Morgantown Energy Research Center fluidized bed combustor and progress in examining corrosion surveillance coupons from the Wilsonville, Alabama, solvent refined coal plant are reported.

- In the gas-fired potassium boiler experiment, about $5 \mathrm{hr}$ of stable boiling operation was obtained at power levels up to about $3.5 \times 10^{6} \mathrm{Btu} / \mathrm{hr}$.

- In the Coal Equipment Test Program, evaluation of potential equipment cest sites is continuing. A comprehensive coal handling and feeding equipment testing/development program is being prepared by JPL, ORNL, MERC \& PERC. . A program plan is being prepared for the survey of industrial capability for coal handling equipment, a new program initiated in January.

- The request for proposal and the performance specifications await final approval from DOE-FE in our AFB Coal Combustor for Cogeneration program. Metallographic examination of samples from three tubes that had a total exposure time of $1500 \mathrm{hr}$ has been completed.

- Editing continued on the Process Modeling project of the physical properties and material balance routines for compilation on the Fortran compiler. A meeting was held with DOE, Purdue University, and Lehigh University representatives on January 25 to review the status of the project.

- A meet1ng was held on January 12 with the DOE Project Manager to discuss reports for a number of engineering support projects including: hot gas purification processes; heat recovery processes; moving bed process for contaminant removal; hydrogen process and flash hydropyrolysis.

- An evaluation was initiated of an in-situ facility for producing methanol which would then be converted to gasoline via the Mobil-M process. An effort was also initiated to develop a computer model for the HYGAS gasifier. 
- The Fossil Energy Environmental Project team reviewed the December 20, 1977 Draft Statement of Work for the Memphis Fuel Gas Demonstration Plant.

- The date for issuing the Program Opportunity Notice for the Atmospheric Fluidized Bed Combustion Demonstration Plant has been delayed in order for DOE to assess the impact of the proposed Environmental Protection Agency requirements on the economic potential of AFBC utility-size plants. 


\title{
2. COAL CONVERSION PROCESS DEVELOPMENT
}

\author{
H. D. Cochran, Jr.
}

Coal conversion process development activities are carried out in the Chemical Technology Division. This section discusses hydrocarbonization studies in a 20-atm bench-scale facility, and engineering support studies for in situ gasification.

\subsection{Hydrocarbonization Research}

E. L. Youngblood, J. Beams, and .T. C. Rose

\subsubsection{Bench-Scale Hydrocarbonization}

Work accomplished. In January we made run $\mathrm{HC}-25$ using Wyodak coal. The run was made at a lower system pressure (150 paig) than used in previous runs to obtain information on the effect of pressure on yields. The run was very smooth with no interruption of feed or other difficulties. Material balance and oil yield data for run $\mathrm{HC}-24$, which was madc using Illinois No. 6 coal that was treated with $\mathrm{Na}_{2} \mathrm{CO}_{3}$, are presented in this report.

The hydrogen flow rates for run $\mathrm{HC}-25$ were reduced to give the same superficial velocity through the reactor and transport line as was used in the two previous runs. In preparation for the run we checked the calibration of the flow meters at the lower operating pressure. The total hydrogen flow rate for the run was 10.8 scfm with 8.2 scfm going to the downcomer and 2.6 scfm to the coal transport line. The reactor temperature was $1060^{\circ} \mathrm{F}$ and the temperature at the top of the draft tube was $1040^{\circ} \mathrm{F}$ throughout the run. Tlie run duracion was $9 \mathrm{hr}$ and $58 \mathrm{~min}$ during which time 109.4 lbs of coal was fed giving an average feed rate of 11 lbs of coal per hour. After startup the system operated at steady state conditions during the remainder of the run. The temperature, gas effluent rate and composition, and other conditions were essentially constant. An additional filter added to the cold trap prior to the run prevented tars from reaching the pressure control valve and resulted in less fluctuation in the effluent gas rate during the run. Also, the sulall amount of fines in the feed $(8.3 \%-170$ mesh) may have contributed to the smoother operation of the coal feeder. The particle size distribution of the coal feed and char for runs HC-23, HC-24, and HC-25 are chown in Table 2.1. Operallun of the feeder was very good in run HC-24 and $\mathrm{HC}-25$, but in run $\mathrm{HC}-23$ the feed rate was lower than expected, probably because of the large amount of fines present. As shown in Table 2.1 the char from each run contained a higher percentage of smaller particles than the feed material.

After the completion of the run, the oil, char, and scrubber water were removed for sampling and analysis. An appreciable amount of oil and 
Table 2.1. Particle size of feed and char from Runs $\mathrm{HC}-23, \mathrm{HC}-24$, and $\mathrm{HC}-25$

\begin{tabular}{|c|c|c|c|c|c|c|c|}
\hline \multirow{2}{*}{\multicolumn{2}{|c|}{$\begin{array}{l}\text { Mesh } \\
\text { size }\end{array}$}} & \multicolumn{2}{|c|}{$\mathrm{HC}-23^{a}$} & \multicolumn{2}{|c|}{$\mathrm{HC}-24^{b}$} & \multicolumn{2}{|c|}{$\mathrm{HC}-25^{\mathrm{C}}$} \\
\hline & & Feed & Char & Feed & Char & Feed & Char \\
\hline & $+45 \%$ & 4.5 & 1.0 & 0.3 & 3.5 & 1.1 & 1.2 \\
\hline-45 & $+60 \%$ & 18.2 & 3.9 & 24.6 & 17.3 & 28.7 & 8.2 \\
\hline-60 & $+80 \%$ & 22.8 & 17.9 & 28.9 & 27.1 & 26.4 & 26.1 \\
\hline-80 & $+120 \%$ & 22.9 & 30.5 & 28.1 & 29.0 & 23.6 & 28.3 \\
\hline-120 & $+140 \%$ & 7.0 & 9.1 & 4.4 & 4.7 & 5.7 & 7.0 \\
\hline-140 & $+170 \%$ & 9.4 & 15.1 & 6.8 & 8.4 & 6.1 & 10.6 \\
\hline-170 & & 15.2 & 22.3 & 6.8 & 9.9 & 8.3 & 18.6 \\
\hline Mean & diameter (in.) & 0.0053 & 0.0043 & 0.0063 & 0.0058 & 0.0062 & 0.0048 \\
\hline
\end{tabular}

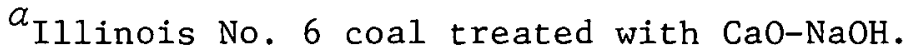

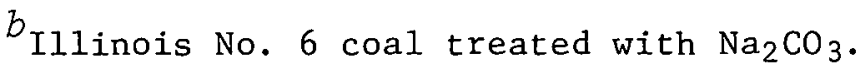

Wyodak coal.

tar was obtained. The system appeared to be in good condition following the run with the exception that the off-gas line from the reactor to the scrubber had a deposit of char and tar that almost blocked the line at the inlet to the scrubber. This deposit occurred at a cold spot where the off-gas enters the scrubber and has also been present after some of the previous runs.

Analytical data have been received for run $\mathrm{HC}-24$ which used Illinois No. 6 coal that had been treated with sodium carbonate as feed. The oil yield for run $\mathrm{HC}-24$ was $24 \%$ (based on maf coal). This yield is higher than the maximum yield (21\%) achieved with runs using Wyodak coal and considerably higher than the yield of $14 \%$ obtained in run $\mathrm{HC}-23$ using Illinois No. 6 coal that had been treated with $\mathrm{CaO}-\mathrm{NaOH}$.

A material balance and summary of the experimental conditions for run HC-24 are given in Tables 2.2 and 2.3. The properties and composition of the oil from run $\mathrm{HC}-24$ that had been centrifuged to remove nost of the char and water are shown in Table 2.4. For comparison purposes the properties and composition of oil from run HC-12 made with Wyodak coal are included in the table. The viscosity of the oil produced in run $\mathrm{HC}-24$ $(120 \mathrm{cs})$ is somewhat higher than that for run HC-12 $(18.4 \mathrm{cs})$. The composition of the two oils are similar to the oil from HC-24 containing more sulfur and the oil from HC-12 containing more oxygen probably because of the higher content of these elements in the teed materials. Simulated boiling point curves for the product from the two runs, shown in Fig. 2.1, are not greatly different. The oil from run HC-24 will be further analyzed by the Gel Partition method to determine the major constituents present. 
Table 2.2. Preliminary material balance for Experiment HC-24

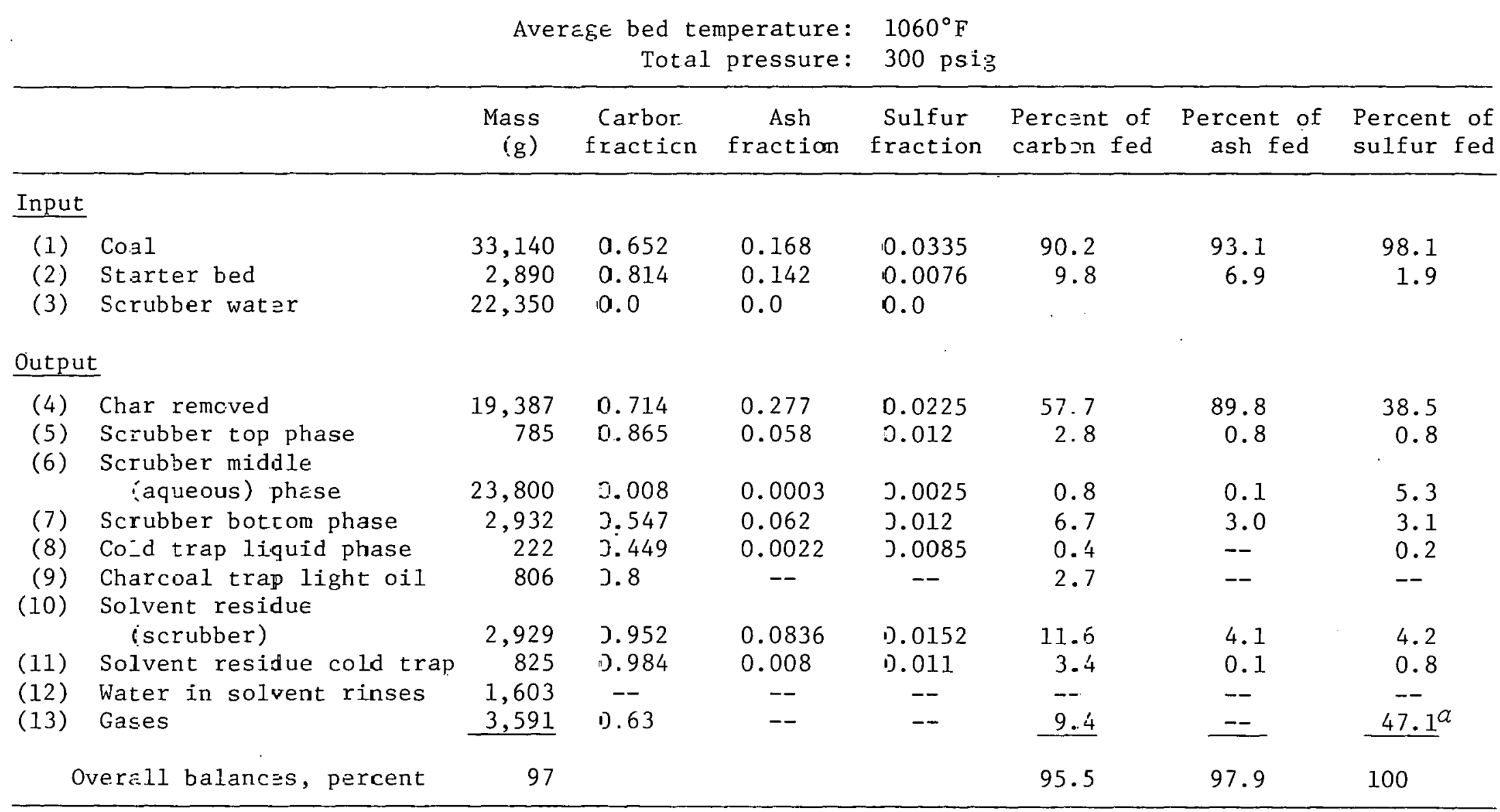

$a_{\text {Calculated b; difference. }}$ 
Table 2.3. Summary of Experiment HC-24 conditions and preliminary material balances

\begin{tabular}{|c|c|}
\hline Experiment & $\mathrm{HC}-24$ \\
\hline $\begin{array}{l}\text { Bed temperature, }{ }^{\circ} \mathrm{F} \\
\text { Reactor pressure, psig } \\
\text { Estimated solids residence time in the reactor, } \min ^{a} \\
\text { Period at steady state, hr }\end{array}$ & $\begin{array}{r}1060 \\
300 \\
46 \\
7.7\end{array}$ \\
\hline $\begin{array}{l}\text { Coal feed }\left(\mathrm{Na}_{2} \mathrm{CO}_{3} \text { treated Illinois No. } 6 \text { coal }\right) \\
\text { Moisture content, wt\% } \\
\text { As-received feed rate, Ib/hr } \\
\text { Moisture-and-ash-free feed rate, } 1 \mathrm{~b} / \mathrm{hr} \\
\text { Time of feeding, hr }\end{array}$ & $\begin{array}{l}4.2 \\
9.5 \\
7.5 \\
7.7\end{array}$ \\
\hline Hydrogen flow rates, scfm & \\
\hline $\begin{array}{l}\text { Total hydrogen feed } \\
\text { Coal transport tube } \\
\text { Draft tube nozzle } \\
\text { Through distributor plate }\end{array}$ & $\begin{array}{r}20 \\
5.0 \\
0.9 \\
14.1\end{array}$ \\
\hline $\begin{array}{l}\mathrm{H}_{2} / \text { coal feed ratio } \\
1 \mathrm{~b} \mathrm{H}_{2} / \mathrm{lb} \text { coal (maf) } \\
\text { scf } \mathrm{H}_{2} / 1 \mathrm{lb} \text { coal (maf) }\end{array}$ & $\begin{array}{l}0.83 \\
160\end{array}$ \\
\hline $\begin{array}{l}\mathrm{H}_{2} \text { consumed } \\
1 \mathrm{~b} \mathrm{H}_{2} / 1 \mathrm{~b} \text { coal (maf) }\end{array}$ & $0.01 \pm 0.02$ \\
\hline Carbon balance $^{b}$ (\% of carbon fed) & \\
\hline $\begin{array}{l}\text { Char } \\
\text { Liquids } \\
\text { Gases } \\
\text { Overall }\end{array}$ & $\begin{array}{l}59 \\
26 \\
10.5 \\
95.5\end{array}$ \\
\hline Nopral1 ash hallance (\% of ash fed) & 98 \\
\hline Sulfur hallance (\% of sulfur fed) & \\
\hline $\begin{array}{l}\text { Char } \\
\text { Liquids } \\
\text { Gases }\end{array}$ & $\begin{array}{l}42 \\
11 \\
47^{c}\end{array}$ \\
\hline Overall mass balance ( $\%$ of mass charged) & 98 \\
\hline Oil yield (wt \% of maf coal) & 24 \\
\hline
\end{tabular}


Table 2.4. Properties and composition of oil from runs $\mathrm{HC}-24$ and $\mathrm{HC}-12$

\begin{tabular}{lcc}
\hline & $\begin{array}{c}\text { Run } \mathrm{HC}-24 \\
\left(\mathrm{Na}_{2} \mathrm{CO}_{3} \text { treated }\right. \\
\text { Illinois No. 6) }\end{array}$ & $\begin{array}{c}\text { Run } \mathrm{HC}-12 \\
\text { Wyodak }\end{array}$ \\
\hline Specific Gravity & 1.1 & 1.07 \\
Viscosity (cs) & & \\
at $100^{\circ} \mathrm{F}$ & 120 & 18.4 \\
at 210 F & -- & 2.6 \\
Composition (\%) & & \\
Muisture & 6.8 & 0.7 \\
Ash & 0.7 & 80.01 \\
Carbon (maf) & 85.8 & 7.4 \\
Ilydrogen (maf) & 7.4 & 1.0 \\
Nitrogen (maf) & 1.2 & 0.3 \\
Sulfur (maf) & 1.5 & 5.9 \\
Oxygen (by difference) & 4.3 & \\
\hline
\end{tabular}

Work forecast. Cleanup and sampling of material from run HC-25 will continue: We will begin preparing coal and the system for the next run which will be made with treated Illinois No. 6 coal.

\subsection{Experimental Engineering Support of In Situ Gasification Processes}

P. R. Westmoreland, L. S. Dickerson and R. L. Andrews

Coal block pyrolysis experiments continued during January, supporting modeling and field development of in situ gasification. Block pyrolysis data are needed for modeling of in situ coal gasification (underground coal gasification) because earlier data described only the pyrolysis of powder samples. By contrast, in situ gasification may react large blocks formed by roof collapse or seam fracturing; possibly it may react. a hrnat seam cross-section. Internal heat and mass transfer resistances are more important, and product yields can change significantly.

In experiments which began at ORNL in 1975, 6-in.-diam $(16 \mathrm{~cm})$ right circular cylinders of subbituminous and bituminous coal have been pyrolyzed by heating the blocks at 0.3 to $14 \mathrm{C}^{\circ} / \mathrm{min}$ (surface temperature) from ambient temperature to maximum temperatures of 500 to $1000^{\circ} \mathrm{C}$. Using an argon or hydrogen purge gas, gas and vapor-phase reaction products are continuously swept from the reactor. Water, oils, and tars are collected in a water-cooled condenser and by filters, and the remaining noncondensible 


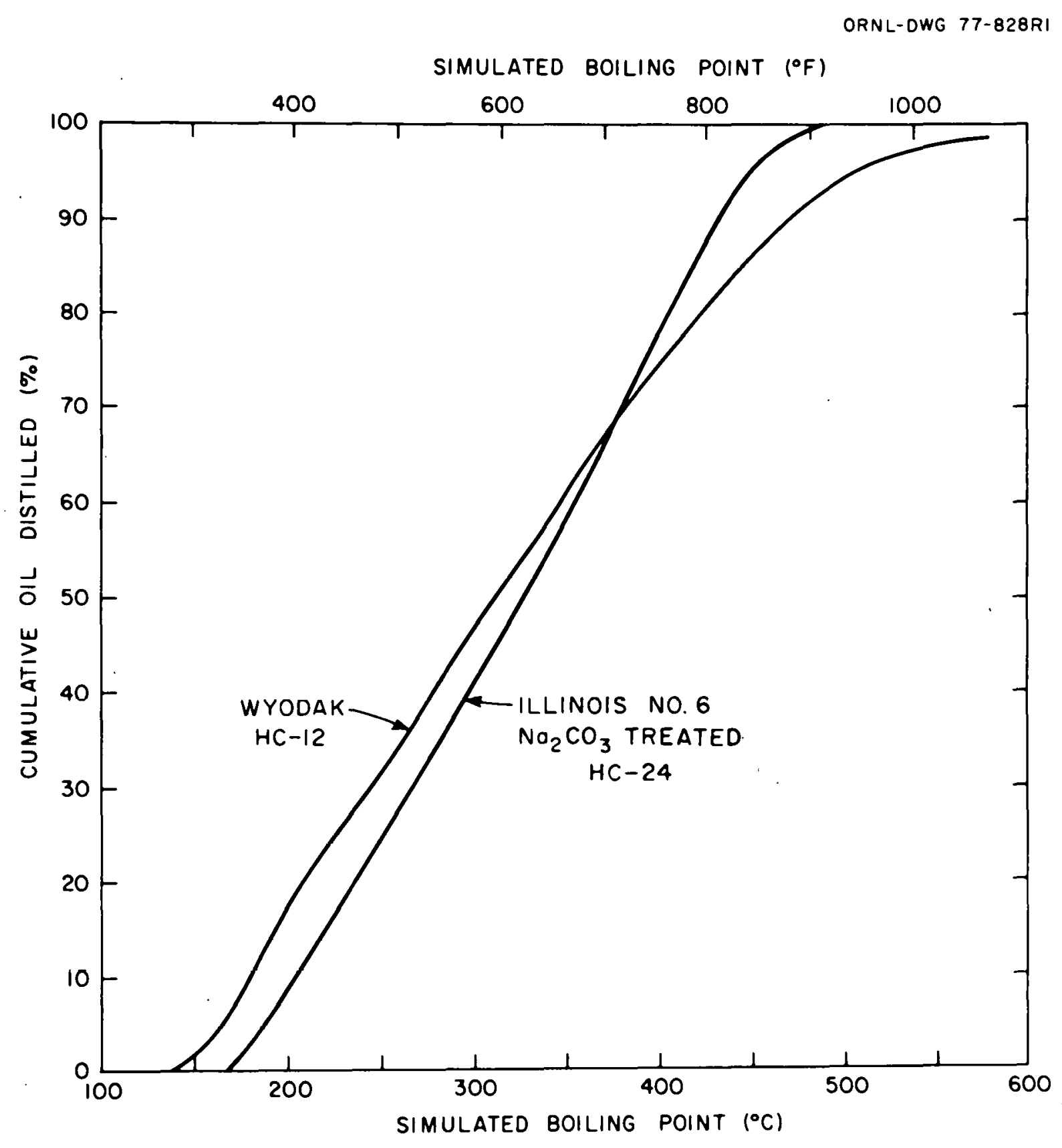

Fig. 2.1. Simulated boiling point curves for oil product from runs $\mathrm{HC}-24$ and $\mathrm{HC}-12$. 
gases are metered and periodically sampled. In many of the experiments, block temperature profiles have been measured by internal thermocouples. These tests are designed to support modeling of field in situ gasification experiments at Laramie Energy Research Center, Lawrence Livermore Laboratory, and Morgantown Energy Research Center (MERC).

Effects of heat and mass transfer resistances have been observed in both subbituminous and bituminous coal block pyrolysis. Swelling of bituminous coal is markedly reduced in tests at higher heating rates. Such change may result from plasticity distributions within the block, as affected by block temperature profiles. Also at higher heating rates, gas evoluation from bituminous coal is increased at the expense of lower char and condensible yields.

\subsubsection{Recent experiments}

Block pyrolysis experiments BP2-42 and BP2-43 were condurted during January. Under an $\mathrm{H}_{2}$ reactor purge gas, bituminous coal blocks were heated at $0.3 \mathrm{C}^{\circ} / \mathrm{min}$ (surface temperature) to 900 and $1000^{\circ} \mathrm{C}$, respectively. The two experiments continue a series of bituminous coal experiments which investigate $\mathrm{H}_{2}$ effects on block pyrolysis (see Table 2.5). For BP2-42 and BP2-42, gas evolution data are summarized in Tables 2.6 and 2.7 .

Plastic flow of the heated block was more extensive in BP2-42 than in any other experiment to date. As in previous experiments at $0.3 \mathrm{C} /$ min, the block swelled laterally from its original diameter of $13.5 \mathrm{~cm}$ to press against the reactor walls $(20.3 \mathrm{~cm})$. Also similarly, the outer rim of the swelling block, pressing against the walls, increased in height from $17.2 \mathrm{~cm}$ to $20.0 \mathrm{~cm}$. However, in this experiment the molten center of the block dropped almost completely out, leaving a crater in the block top that was $11.9-\mathrm{cm}-\mathrm{diam}$ and $17.2-\mathrm{cm}$-deep $(14.3 \mathrm{~cm}$ below the original top of the block). This flowing, plastic coal filled the bottom of the reactor at a reactor temperature of $900^{\circ} \mathrm{C}$, as indicated by fluctuations in thermocouple measurements.

\section{2 .2 Heating rate effects on condensihles yield}

Detailed analysis of cundensibles from experiments BP2-37, BP2-38, and BP2-39 indicate the effect of heating rate on yield of condensibles. These experiments were all conducted using bituminous coal blocks heated to $900^{\circ} \mathrm{C}$ under $\mathrm{H}_{2}$, but heating rates of $0.3,3$, and $14 \mathrm{C}^{n} / \mathrm{min}$ at the block surfaces were used.

Decreasing H/C atomic ratio of organic condensibles is the only apparent composition trend as heating rate increases (see Table 2.8). From the block pyrolysis experiment carried out at $0.3 \mathrm{C} / \mathrm{min}$ to the experiment conducted at $3{ }^{\circ} \mathrm{C} / \mathrm{min}$ and the experiment conducted at $14 \mathrm{C}^{\circ} /$ $\mathrm{min}, \mathrm{H} / \mathrm{C}$ ratios dropped from 1.26 to 0.92 to 0.89 , respectively. By comparison, the ratio for naphthalene is 0.8 ; the bituminous coal block, 0.88 ; benzene, 1.0 ; butadiene, $1.5 ; \mathrm{n}$-decane, 2.2 ; and methane, 4.0. 
Table 2.5. Summary of experimental conditions for pyrolysis experiments using a hydrogen cover gas and bituminous coal block ${ }^{\alpha}$

\begin{tabular}{|c|c|c|c|c|c|c|c|c|}
\hline \multirow{3}{*}{$\begin{array}{c}\text { Run } \\
\text { number }\end{array}$} & \multirow{3}{*}{$\begin{array}{l}\text { Date of } \\
\text { run }\end{array}$} & \multirow{3}{*}{$\begin{array}{l}\text { Heating } \\
\text { rate } \\
\left(\mathrm{C}^{\circ} / \mathrm{min}\right)\end{array}$} & \multirow{3}{*}{$\begin{array}{c}\text { Maximum } \\
\text { temperature }\end{array}$} & \multirow{3}{*}{$\begin{array}{c}\mathrm{H}_{2} \text { cover } \\
\text { gas flow rate } \\
(\mathrm{S} t \mathrm{~d} . \text { liter } / \mathrm{min})\end{array}$} & \multicolumn{4}{|c|}{ Coal block } \\
\hline & & & & & \multicolumn{2}{|c|}{ Dimensions $(\mathrm{cm})$} & \multicolumn{2}{|c|}{ Weight } \\
\hline & & & & & Hej.ght & Diameter & $(\mathrm{kg})$ & $(\mathrm{kg} \operatorname{maf})$ \\
\hline $\mathrm{BP} 2-33$ & $8 / 13 / 77$ & 3 & $600(640)$ & 2.90 & 24.0 & 15.7 & 6.133 & 5.811 \\
\hline EP2-34 & $8 / 31 / 77$ & 3 & 1000 & 2.95 & 17.8 & 15.2 & 4.564 & 4.323 \\
\hline RP 2-35 & $9 / 21 / 77$ & 3 & 800 & 2.95 & 21.9 & 15.2 & 5.384 & 5.100 \\
\hline EP 2-37 & $10 / 17 / 7 ?$ & 3 & $900 \quad(880)$ & 3.08 & 18.4 & 15.1 & 4.217 & 3.995 \\
\hline EP 2-38 & $10 / 31 / 7 ?$ & 14 & $900(890)$ & 2.90 & 19.7 & 15.4 & 4.658 & 4.413 \\
\hline EP 2-39 & $11 / 14 / 77$ & 0.3 & $900(925)$ & 3.00 & 22.5 & 14.9 & 5.000 & 4.737 \\
\hline E.P2-41 & $12 / 15 / 77$ & 0.3 & 600 & 3.00 & 21.3 & 13.5 & 4.820 & 4.566 \\
\hline EP $2-42$ & $1 / 10 / 78$ & 0.3 & $900^{b}$ & 2.69 & 15.1 & 13.5 & 3.676 & 3.482 \\
\hline EP2 $2-43$ & $1 / 31 / 78$ & 0.3 & $1000(1032)$ & $3.07^{c}$ & 17.1 & 15.1 & 3.492 & 3.308 \\
\hline
\end{tabular}

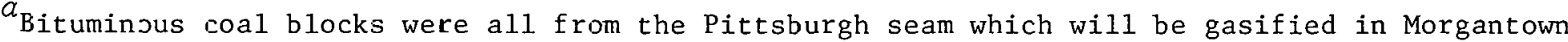
Energy Research Center field tests.

$b_{\text {Reached }} 900^{\circ}$ uniform temperature before pyrolysis reactions were quenched by lowering the reactor temperature.

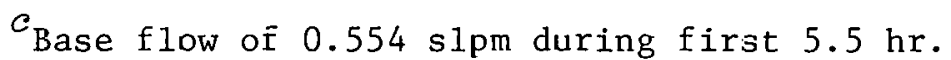

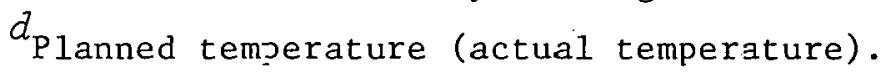


Table 2.6. S ummary of preliminary gas evolution data from experiment $\mathrm{BP} \angle-42$ (block pyrolysis of bituminous $\operatorname{coal}=0905^{\circ} \mathrm{C}$ at $0.3 \mathrm{C} / \mathrm{min}, \mathrm{H}_{2}$ purge gas)

\begin{tabular}{|c|c|c|c|c|c|c|c|c|}
\hline & Total & $\mathrm{H}_{2}$ & $\mathrm{CH}_{4}$ & $\mathrm{C}_{2}{ }^{\prime} \mathrm{s}$ & $\mathrm{C}_{3}{ }^{\prime} \mathrm{s}$ & $\mathrm{CO}$ & $\mathrm{CO}_{2}$ & $\mathrm{H}_{2} \mathrm{~S}$ \\
\hline \multicolumn{9}{|l|}{ Gas evolution } \\
\hline Volumetric (std. liters) & 682.1 & $3 I .2$ & 428.6 & 31.14 & 9.72 & 76.68 & 14.70 & 90.03 \\
\hline Normalized (std. $\ell / \mathrm{kg}$ maf coal) & 195.9 & 8.96 & 123.1 & 8.94 & 2.79 & 22.02 & 4.22 & 25.86 \\
\hline Mass (g) & 635.1 & 2.81 & 306.9 & 41.15 & 18.83 & 95.88 & 28.9 & 137.0 \\
\hline Normalized (g/kg maf) & $18 \varepsilon .4$ & 0.807 & 88.14 & 11.82 & 5.41 & 27.54 & 8.29 & 39.3 \\
\hline $\begin{array}{l}\text { Average composition of evolved gas } \\
\text { (Vol } \%)\end{array}$ & -- & 4.57 & 62.8 & 4.57 & 1.43 & 11.24 & 2.16 & 13.2 \\
\hline \multicolumn{9}{|l|}{ Elemental composition $(\mathrm{g})$} \\
\hline $\begin{array}{l}\text { Carbon } \\
\text { Hydrogen } \\
\text { Sulfur } \\
\text { Oxygen }\end{array}$ & $\begin{array}{r}325.8 \\
99.0 \\
12 \varepsilon .9 \\
77.77\end{array}$ & & & & & & & \\
\hline $\begin{aligned} \text { Gas higher heating jaIue } & (\mathrm{MJ}) \\
& (\mathrm{Btu}) \\
& (\mathrm{Btu} / \mathrm{scf})\end{aligned}$ & $\begin{array}{l}25.5 \\
24211 \\
933\end{array}$ & & & & & & & \\
\hline $\begin{array}{l}\text { Gas efficiency (Btu in gas/Btu in } \\
\text { coal) }\end{array}$ & $21.6 \%$ & & & & & & & \\
\hline
\end{tabular}


Table 2.7. Summary of preliminary gas evolution data from experiment BP2-43 (block pyrolysis of bituminous coal to $1032^{\circ} \mathrm{C}$ at $0.3 \mathrm{C}^{\circ} / \mathrm{min}, \mathrm{H}_{2}$ purge gas)

\begin{tabular}{|c|c|c|c|c|c|c|c|c|}
\hline & Total & $\mathrm{H}_{2}$ & $\mathrm{CH}_{4}$ & $\mathrm{C}_{2}{ }^{\prime} \mathrm{s}$ & $\mathrm{C}_{3}{ }^{\prime} \mathrm{s}$ & $\mathrm{CO}$ & $\mathrm{CO}_{2}$ & $\mathrm{H}_{2} \mathrm{~S}$ \\
\hline \multicolumn{9}{|l|}{ Gas evolution } \\
\hline Volumetric (std. liters) & 681.5 & $161.2^{\approx}$ & 343.3 & 41.11 & 12.62 & 81.15 & 19.77 & 22.4 \\
\hline Normalized (std. $\ell / \mathrm{kg}$ maf coal) & 206.02 & 48.7 & 103.78 & 12.43 & .3 .82 & 24.53 & 5.98 & 6.78 \\
\hline Mass $(g)$ & 513.5 & 14.51 & 245.8 & 54.3 & 24.5 & 101.5 & 38.84 & 34.12 \\
\hline Normalized ( $g / k g$ maf $)$ & 155.23 & 4.39 & 74.30 & 16.41 & 7.41 & 30.7 & 11.74 & 10.31 \\
\hline $\begin{array}{l}\text { Average composition of evolved gas } \\
(\text { Vol } \%)\end{array}$ & -- & 23.7 & 50.4 & 6.03 & 1.85 & 11.91 & 2.90 & 3.29 \\
\hline \multicolumn{9}{|l|}{ Elemental composition ( $\mathrm{g}$ ) } \\
\hline $\begin{array}{l}\text { Carbon } \\
\text { Hydrogen } \\
\text { Sulfur } \\
\text { Oxygen }\end{array}$ & $\begin{array}{r}302.5 \\
92.8 \\
32.1 \\
86.2\end{array}$ & & &. & & & & \\
\hline $\begin{aligned} \text { Gas higher heating value } & (M F) \\
& (B t u) \\
& (B t u / s c f)\end{aligned}$ & $\begin{array}{l}22.94 \\
21743 \\
839\end{array}$ & . & - & : & & & . & \\
\hline $\begin{array}{l}\text { Gas efficiency (Btu, in gas/Btu in } \\
\text { coal) }\end{array}$ & $19.3 \%$ & & & & & & & \\
\hline
\end{tabular}

$a_{\mathrm{Net}} \mathrm{H}_{2}$ produced. 
Tab 1.e 2.8. Heating rate effects on oi.1 and tar composition (block pyrolysis of bituminous coal in $\mathrm{H}_{2}$ purge gas)

\begin{tabular}{|c|c|c|c|}
\hline Surface heating rate $\left(\mathrm{C}^{\circ} / \mathrm{min}\right)$ & 0.3 & 3 & 14 \\
\hline Maximum temperature $\left({ }^{\circ} \mathrm{C}\right)$ & 900 & 900 & 900 \\
\hline Experiment & BP $2-39$ & BP 2-37 & BP 2-38 \\
\hline \multicolumn{4}{|c|}{$\begin{array}{l}\text { Oil and tar elemental composition } \\
\text { (wt \% maf) }\end{array}$} \\
\hline$c$ & 84.7 & 88.3 & 87.5 \\
\hline $\mathrm{H}$ & 8.97 & 6.8 & $\dot{b} .51$ \\
\hline $\mathrm{N}$ & 1.17 & 1.48 & 1.41 \\
\hline $\mathrm{S}$ & 1.75 & 2.07 & 1.31 \\
\hline$o^{\alpha}$ & 3.5 & 1.5 & 3.4 \\
\hline $\mathrm{H} / \mathrm{C}$ atomic ratio & 1.26 & 0.92 & 0.89 \\
\hline
\end{tabular}

As shown in Table 2.9, effects of heating rate on yield of condensibles are much clearer. Yields are normalized for block size by reporting grams of condensibles per $\mathrm{kg}$ of moisture-and-ash-free coal. As heating rate is increased, water production increacec from 8.8 (which would be expected from drying alone) to 26.8 at $0.3 \mathrm{C}^{\circ} / \mathrm{min}, 55.3$ at $3 \mathrm{C}^{\circ} /$ min, and 64.5 at $14 \mathrm{C}^{\circ} / \mathrm{min}$. In contrast, production of oils and tars decreases from 146.2 to 85.8 to 66.2 . The overall effect is a $23 \%$ decrease in the total amount of condensibles from block pyrolysis at $1 . / \mathrm{C}^{0} / \mathrm{min}$ compared to $0.3 \mathrm{C}^{\circ} / \mathrm{min}$.

Each of these effects is consistent with the hypothesis that secondary cracking reactions of pyrolysis producte become more important at higher heating rates. From the $\mathrm{H} / \mathrm{C}$ ratio, condensed ring structures and unsaturated hydrocarbons typical of severe cracking may have been produced. Decreased yield of organic condensibles (the reactants for secondary cracking) and increased yields of water (as a product of pyrolysis) also support the hypothesis.

Such an Increase in secuilday cracking could result from heat and mass transfer resistances within the coal block. Because of internal mass transfer resistances, pyrolysis products do not escape immediately from the block interior, but must negotiate some path out of the block by convection or diffusion. Because of internal heat transfer resistances, block temperatures are nearly uniform at $0.3 \mathrm{C}^{\circ} / \mathrm{min}$, but at higher heating rates, steeper thermal gradients can exist between the hot block surface and cooler center. A simultaneous effect of these resistances could be secondary cracking of pyrolysis products from the block center as the products move outward through the hotter surface regions. Less effect 
Table 2.9. Heating rate effects on condensibles yield (block pyrolysis of bituminous coal in

$\mathrm{H}_{2}$ purge gas)

\begin{tabular}{|c|c|c|c|c|}
\hline \multicolumn{2}{|c|}{ Surface heating rate $\left(\mathrm{C}^{\circ} / \mathrm{min}\right)$} & 0.3 & 3 & 14 \\
\hline \multicolumn{2}{|l|}{ Maximum temperature $\left({ }^{\circ} \mathrm{C}\right)$} & 900 & 900 & 900 \\
\hline \multicolumn{2}{|l|}{ Experiment } & BP $2-39$ & $\mathrm{BP} 2-37$ & BP $2-38$ \\
\hline \multicolumn{5}{|c|}{ Condensibles yield ( $\mathrm{g} / \mathrm{kg}$ maf coal) } \\
\hline \multicolumn{2}{|l|}{ Water } & 26.8 & 55.3 & 64.5 \\
\hline \multicolumn{5}{|l|}{ Oils and tars } \\
\hline \multirow[t]{5}{*}{ Elemental breakdown: } & $\mathrm{C}$ & 123.5 & 75.8 & 57.8 \\
\hline & $\mathrm{H}$ & 13.09 & 5.83 & 4.30 \\
\hline & $\mathrm{N}$ & 1.71 & 1.25 & 0.93 \\
\hline & $\mathrm{S}$ & 2.55 & 1.78 & 0.86 \\
\hline & $0^{a}$ & 5.07 & 1.33 & 2.27 \\
\hline \multicolumn{2}{|l|}{ Total oils and tars } & 146.2 & 85.8 & 66.2 \\
\hline \multicolumn{2}{|l|}{ Total condensibles } & 170.6 & 141.2 & $\underline{\underline{130.7}}$ \\
\hline
\end{tabular}

of heat transfer resistance would be present at lower heating rates, although internal mass transfer might be slowed by the increased plastic deformation of the block structure.

\subsubsection{Work forecast}

During February, bituminous coal block experiments will continue. Experiments at $0.3 \mathrm{C}^{\circ} /$ min to $600^{\circ} \mathrm{C}$ and $800^{\circ} \mathrm{C}$ are planned. Critical review and analysis of gas data will continue. 


\section{MATERIALS ENGINEERING}

R. T. King

The materials engineering and associated technology reported here are in support of activities directed by the Materials Branch of the Division of Coal Conversion, DOE, in the Fossil Energy Program. Other related work not funded directly by this division of $\mathrm{DOE} / \mathrm{FE}$ is included also.

\section{Summary}

The toughness of $21 / 4 \mathrm{Cr}-1$ Mo in thick sections suitahle for large coal conversion systems is being explored for material in the as-fabricated condition. Preparation of a facility for environmental exposure of materials is underway.

Equipment modifications for plasma spraying of CoCrAlY have been completed. We are debugging the modified reflection-coil computer program for eddy current testing; our through-transmission computer program operates satisfactorily. We made two tensile crack specimens from the metalliccoated ANL (C5) specimen as an interim measure until CoCrAlY specimens become available. Closeout work on two cermet penetrant specimens was also performed. Construction of the scanning thermometric probe for unbond detection in CoCrAlY coated specimens has begun.

A range of welding parameters have been found for depositing type $320 \mathrm{Cb}$ stainless steel on carbon steel clad with Inconel 82 that produces no cracking on the finished surface. Some internal fissuring was found metallographically; the extent of internal fissuring appears to be related to the amount of nirkel dilution in cucccssive passes. We are making depustes on 2 1/4 ir-1 substrate material.

The corrosion data for types 304,316 , and 310 stainless steel, Alloy 600, and Alloy 800 exposed to the Fluidyne atmospheric fluidized bed combustor for $500 \mathrm{hr}$ and $1500 \mathrm{hr}$ are summarized in this report. HighLemperature specimens for a. $3000 \mathrm{hr}$ run have been prepared.

A failure analysis of heat exchanger tubes from the Morgantown Energy Research Center flulidized bed combustor and progress in examining corrosion surveillance coupons from the Wilsonville, Alabama Solvent Refined Coal Plant are repurted.

\subsection{Pressure Vessel and Piping Materials}

$$
\text { W. J. Stelzman and D. A. Canonico }
$$

We have continued to investigate the effect of tempering and stress relief on the $21 / 4 \mathrm{Cr}-1$ Mo specimen bars which had received simulated 
cooling rates in our Data Trak facility. The bars had received nominal quench rates of $0.3 \mathrm{~K}(0.6 \mathrm{R}) / \mathrm{s}$ and $3 \mathrm{~K}(5 \mathrm{R}) / \mathrm{s}$ from $972^{\circ} \mathrm{C}\left(1700^{\circ} \mathrm{F}\right)$ and $3 \mathrm{~K}$ $(5 \mathrm{R}) / \mathrm{s}$ from $1038^{\circ} \mathrm{C}\left(1900^{\circ} \mathrm{F}\right)$. Groups of bars from each condition were subjected to one of three additional treatments: tempering at $704^{\circ} \mathrm{C}\left(1300^{\circ} \mathrm{F}\right)$ for $1 \mathrm{hr}$ and tempering at $704^{\circ} \mathrm{G}$ for $1 \mathrm{hr}$ followed by stress relieving at $677^{\circ} \mathrm{C}\left(1250^{\circ} \mathrm{F}\right)$ for either 40 to $120 \mathrm{hr}$. All of the heat treatments are complete and the bars have been sent out for machining into Charpy or tensile specimens. Testing of the specimens will begin as soon as the specimens have been returned.

\subsection{Inspection Techniques for Wear- and Process-Resistant Coatings}

R. W. McClung and G. W. Scott

\subsubsection{Specimens and Standards (G. W. Scott and D. P. Edmonds)}

We received and installed the replacement plasma spraying torch for CoCrAlY specimens. The new torch uses a different arc-starter, the installation of which required significant electrical modifications to the system. We expect to finish spraying the first group of CoCrAlY specimens during February.

\subsubsection{Eddy Current Testing (G. W. Scott and C. V. Dodd)}

During the transfer of data gathering and evaluating routines from the laboratory time-sharing system to our NDT lab computer, some program modifications were required and some optional improvements were added. The section of our reflection coil program used for drift calculations is still being debugged, so estimates of effects such as substrate conductivity variation cannot be calculated yet. We have been able to perform studies of coil size and frequency effects to confirm estimates from older design data. As predicted, coils with $0.5 \mathrm{~mm}$ (0.0202 in.) radius perform best at $10 \mathrm{MHz}$, but can be operated as low as $1 \mathrm{MHz}$ with adequate sensitivity.

The program for through-transmission measurement of permeability and conductivity (p.lanned for use with free-layer coating specimens) has been tested and appears to function correctly. We will use it on specimens as they become available.

\subsubsection{Surface Inspertion Materials (S. D. Snyder)}

Two more redesigned tensile-crack specimens were coated with cermet and cracked. One of these specimens, $\mathrm{CP} 72-\mathrm{C} 03$, has a $0.25-\mathrm{mm}(0.010 \mathrm{in.})$ thick layer of $50 \% \mathrm{ZrO}_{2}-50 \% \mathrm{NiZrAl}$ on a IN-800 substrate; the other, $\mathrm{CP} 72 \mathrm{~T}-\mathrm{C} 02$, has a $0.075-\mathrm{mm}$ ( $0.003 \mathrm{in.})$ thick binder coat of NiCrAl alloy on the IN-800 substrate with a $0.25 \mathrm{~mm}$ ( 0.010 in.) thick layer of $50 \% \mathrm{ZrO}_{2}-$ $50 \% \mathrm{NiCrAl}$ cermet on the binder coat. Specimen CP72-C03 cracked after being subjected to a $22.5 \mathrm{kN}$ (5000 lb) tensile load. The cracks did not 
appear until a short time after the load was removed completely. This cracking behavior is similar to that of the specimen reported last month.

Specimen CP72T-C02 (with the binder coat) was tensile loaded to $22.5 \mathrm{kN}(5000 \mathrm{lb})$ and unloaded also. When no cracks appeared after the load was removed, it was reloaded and cracked at $23.4 \mathrm{kN}(5200 \mathrm{lb})$.

A test using the established penetrant reversal technique with $\mathrm{ZL}-30 \mathrm{~A}$ penetrant on cracked specimen $\mathrm{CP} 72-\mathrm{C} 02$ showed that these cracks are tighter than those produced by bending in specimen CP72-C01. Penetrant removal from the cracks in the tensile-cracked specimen was considerably less than from the cracks in the best specimen.

Now that intermetalliic coatings are being emphasized over ceramic or cermet coatings, we decided to cut the Argonne National Laboratory intermetallic coated specimen, ANL-C5, into tensile-crack specimens. This is to provide interim specimens until CoCrAlY coated specimens become availuble. We cul two pieces from the $5 \times 5 \mathrm{~cm}(2 \times 2$ in. $)$ ANL-C5 specimen, each $5 \mathrm{~cm}$ (2 in.) long with a minimum throat width of $9.5 \mathrm{~mm}(0.375 \mathrm{in.})$ and a $5.72 \mathrm{~cm}$ ( $2.5 \mathrm{in.})$ radius of curvature. Both specimens were tensile loaded. Une cracked at $9.8 \mathrm{kN}(2175 \mathrm{lb})$ and the other at $10.9 \mathrm{kN}(2425 \mathrm{lb})$. These cracks appear to be wider, straighter, and more nearly continuous than the cracks in the cermet coating when radiographs of the two cracked coatings are compared.

\subsubsection{Thermal Testing (W. A. Simpson, Jr.)}

A prototype thermal probe has been fabricated for automated testing of coated surfaces. The thermistor sensor has not yet been installed in the probe; because of its small size, it will probably bc asseimled by an outside firm which specializes in the construction of subminiature plertrical coils. A design for a bridge-type detector is being tested and will be constructed following evaluation.

\subsection{Fossil Energy Welding and Cladding Program \\ D. P. Edmonds, J. J. Woodhouse, and J. D. Hudson}

Clad specimens of type $320 \mathrm{Cb}$ stainless steel. on carbon stcel base metal with an intermediate layer of Inconel 82 have been evaluated metallographically. These specimens (JW18-JW26) were prepared using the gas metalarc (GMA) process. The Inconel layers were deposited using a constant set of conditions and the type 320 layers were deposited using welding currents of $220 \mathrm{~A}$, voltages of $26 \mathrm{~V}$, oscillation speeds ranging from 6 to $21 \mathrm{~mm} / \mathrm{s}$, and oscillation widths ranging from 6 to $32 \mathrm{~mm}$. Similar deposits made previously (JW9-JW17), without intermediate Inconel layers, had exhibited high susceptibilities to fissuring. However, dye-penetrant examination of these deposits revealed no cracks open to the clad surfaces. 
Metallographic evaluation of sections taken normal to the clad surface revealed no fissures in the intermediate layers, but several fissures in the type $320 \mathrm{Cb}$ layers of various deposits. None of these cracks had propagated to the surface. The fissures were found in those deposits made with higher oscillation speeds and widths. In general, dilutions decrease as oscillation speeds and widths increase for these deposits. Therefore, for the GMA deposits the tendency for fissuring decreases as the dilution from the Inconel interlayer increases. This condition is believed to result from the higher nickel concentrations in the higher dilution deposits.

\subsection{Fireside Corrosion of Atmospheric Fluidized Bed Combustor Tubes}

T. G. Godfrey and J. H. DeVan

\subsubsection{Fluidyne 1500-hr Test}

We have completed thickness measurements of the surface and intergranular oxide films on the heat exchanger tubes exposed in the Fluidyne AFBC for 1500-hr. The results are reported in Table 1. Representative photomicrographs and descriptions of these samples were given previously. ${ }^{1}$ Also reported in Table 1 are corrected results for the previously reported 500-hr samples. ${ }^{2}$ This was necessary because a different measurement and analysis procedure has been adopted for the 1500-hr samples, and this required remeasurement of the earlier samples. Also, errors were found in the previous table that stemmed from unit conversions.

Our new measurements of scale thickness and corrosion depths were made using a digital measuring eyepiece and a Bausch and Lomb metallograph at a magnification of $320 x$. The measurements were made at eight equally spaced points on the inner and outer circumferences of the polished cross sections. The samples were rotated several degrees of arc at each location in order to locate the thickest oxide scale or the deepest discernable corrosion feature. In contrast to the earlier work, zeroes were not allowed (the absence of scale locally really means that the scale has been lost in handling). If scale or corrosion could not be located within a particular field, that area was not used in the calculations. The top of the tube, as exposed in the FBC, was identified and was the $0^{\circ}$ reference for the angular measurements. In no case, however, was a statistically significant angular dependence of scale or corrosion detected. The tubes were sectioned a minimum of three times along their heated lengths, corresponding to temperatures from 1550 to $1625^{\circ} \mathrm{C}$, but no significant temperature effects were found. The results in Table 1 thus represent overall averages for each material examined.

Tube wall thickness of all samples together with control samples were measured using a toolmakers microscope. Although the results are not totally conclusive, since pre-test measurements were not made on exactly the same tubing section that was exposed in the $F B C$, the differences observed were well within manufacturing tolerances for the tubing employed. Also, no angular dependence of wall thickness could be statistically 
Table 1. Summary of Metallographic Analysis of Tube Samples After 500- and 1500-hr Exposure in Fluidyne FBC

\begin{tabular}{|c|c|c|c|c|c|c|c|}
\hline \multirow[b]{2}{*}{ Material } & \multirow[b]{2}{*}{$\begin{array}{l}\text { Time } \\
\text { (hr) }\end{array}$} & \multicolumn{3}{|c|}{ Oxide Scale, $\mu \mathrm{m}$} & \multicolumn{3}{|c|}{ Intergranular, $\mu \mathrm{m}$} \\
\hline & & Avg.a & $\begin{array}{l}\text { Std.b } \\
\text { Dev. }\end{array}$ & $\operatorname{Max} . c$ & Avg. $a$ & $\begin{array}{l}\text { Std.b } \\
\text { Dev. }\end{array}$ & $\operatorname{Max} . c$ \\
\hline & & \multicolumn{6}{|c|}{ Air Side } \\
\hline 304 & $\begin{array}{c}500 \\
1500 d\end{array}$ & 5.54 & 3.52 & 16.01 & 14.64 & 6.23 & 24.94 \\
\hline 310 & $\begin{array}{r}500 \\
1500\end{array}$ & $\begin{array}{l}4.25 \\
5.26\end{array}$ & $\begin{array}{l}0.97 \\
1.00\end{array}$ & $\begin{array}{l}6.36 \\
7.64\end{array}$ & $\begin{array}{l}13.30 \\
17.01\end{array}$ & $\begin{array}{l}3.87 \\
6.74\end{array}$ & $\begin{array}{l}28.81 \\
40.66\end{array}$ \\
\hline 316 & $\begin{array}{l}500 d \\
1500\end{array}$ & 5.97 & 0.86 & 7.42 & 25.69 & 8.03 & 40.56 \\
\hline 600 & $\begin{array}{c}500 \\
1500 e\end{array}$ & 4.04 & 0.75 & 5.68 & 12.68 & 3.04 & 20.65 \\
\hline 800 & $\begin{array}{r}500 \\
150 n\end{array}$ & $\begin{array}{l}5.53 \\
7.19\end{array}$ & $\begin{array}{l}1.53 \\
1.32\end{array}$ & $\begin{array}{l}10.10 \\
10.44\end{array}$ & $\begin{array}{l}42.85 \\
49.17\end{array}$ & $\begin{array}{l}5.31 \\
9.29\end{array}$ & $\begin{array}{l}55.62 \\
83.41\end{array}$ \\
\hline & \multicolumn{7}{|c|}{ Coal Side } \\
\hline 304 & $\begin{array}{c}500 \\
1500 d\end{array}$ & 5.94 & 2.38 & 12.54 & 16.11 & 6.24 & 39.82 \\
\hline 310 & $\begin{array}{r}500 \\
.1500\end{array}$ & $\begin{array}{l}4.74 \\
6.19\end{array}$ & $\begin{array}{l}1.17 \\
1.83\end{array}$ & $\begin{array}{r}6.76 \\
12.70\end{array}$ & $\begin{array}{l}13.08 \\
15.73\end{array}$ & $\begin{array}{l}5.45 \\
3.92\end{array}$ & $\begin{array}{l}30.76 \\
32.41\end{array}$ \\
\hline 316 & $\begin{array}{c}500 d \\
1500\end{array}$ & 7.51 & 2.51 & 10.80 & .41 .64 & 8.26 & 5.34 \\
\hline 600 & $\begin{array}{c}500 \\
15000\end{array}$ & 3.96 & 0.81 & 4.13 & 14.09 & 3.88 & 20.96 \\
\hline 800 & $\begin{array}{r}500 \\
1500\end{array}$ & $\begin{array}{l}5.64 \\
7.42\end{array}$ & $\begin{array}{l}1.49 \\
1.33\end{array}$ & $\begin{array}{l}8.94 \\
9.84\end{array}$ & $\begin{array}{l}34.54 \\
30.91\end{array}$ & $\begin{array}{l}10.77 \\
12.1 .3\end{array}$ & $\begin{array}{l}63.89 \\
65.91\end{array}$ \\
\hline
\end{tabular}

Average of all measurements on material typc.

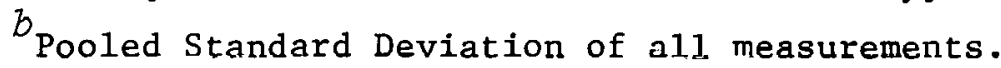

${ }^{c}$ Maximum feature observed.

$d_{\text {Sample not yet available. }}$

${ }^{e} \mathrm{All}$ Inconel 600 samples removed from test shortly beyond $500 \mathrm{hr}$. 
detected. (For the upcoming 3000-hr test, measurements of tube-wall thickness were made by micrometer at precise points on each tube to be exposed so there can be no question of the interpretation of post-test results.)

The results in Table 1 show that oxide scale thicknesses on the air and coal sides do not vary greatly for a given material or from one material to another. This indicates that the sulfate coating that forms on the coal side is not harmful to the protective oxide and, indeed, may be helpful in lessening the gentle abrading action of the fluidized bed. Note that the depth of intergranular corrosion on the air-side approaches or even exceeds that on the coal side. This air-side corrosion is. considered to be abnormal, and suggests the presence of some extraneous contaminant. The fiberglassinsulated thermocouples that extended the length of the tubes internally represent a possible source of contaminant, and this is being investigated in an auxilary experiment. The intergranular corrosion observed on the coal side after $1500 \mathrm{hr}$ appears to separate the materials into two groups: a lower group consisting of 304 and 310 stainless steels and Inconel 600, and a higher group, 316 stainless steel and Incoloy 800. In the case of 310 stainless steel and Alloy 800, where the data set is complete, the $1500 \mathrm{hr}$ results are nearly identical with the $500 \mathrm{hr}$ ones. (The data sets for 304 and 316 stainless steel will be completed as a part of the upcoming 3000-hr experiment.)

Measurements were also made of the Alonized 310 and 800 alloy samples but are not reported because it is not yet clear how to translate the results into corrosion rates. The outer aluminum coating was essentially totally destroyed, while the underlying diffusion zone was essentially unaffected.

\subsubsection{Preparation of Tubes for 3000-hr Test}

The high-temperature tubes for the upcoming 3000-hr extension of the 1500-hr test at FluiDyne have been prepared and are ready for shipment to Fluidyne. Final preparation of the low-temperature composite tubes of 304 stainless steel and $21 / 4 \mathrm{Cr}-1$ Mo awaits the results of a shakedown test to be performed in the FBC using the prototype tubes described previously.

\subsection{Failure Analysis and Prevention}

\section{R. T. King}

3.5.1 MERC FBC In-Bed Heat Exchanger Failure (T. G. Godfrey, R. S. Crouse, and M. D. Allen)

Portions of six failed U-bend heat exchanger tubes from the AFBC at the Morgantown Energy Research Center were received for examination. The tubes were uncooled 1/2-in. NPS, sch. 160, type 316 stainless steel and had experienced approximately 100-hr exposure in the FBC. At the time of failure, the fluidized bed was in approximately steady state operation at $1650^{\circ} \mathrm{F}$ with steady coal feed and $1350 \mathrm{ppm} \mathrm{SO}_{2}$ in the flue gas. 
The tubes failed by apparent melting as shown in Figs. 3.1 and 3.2. Several inches of tube length at the center of the bed were melted and lost. One intact half of a U-tube showed severe corrosion at mid-length, and we surmise that this portion was nearest the side-wall of the FBC, most distant from the central, single coal-feed point.

Metallographic and electron microprobe examination revealed the following:

1. a high concentration of sulfur in the melted region present as a second phase in the Fe-Cr-Ni melted matrix,

2. a sulfur-rich scale-like melted region on the inside and outside surfaces of the still-intact pipe wall near the fully melted zone, and,

3. a very coarse grain size throughout the intact portion of the pipe wall near the melted zone.

Further tests are in progress, but the evidence in hand clearly indicates the fallure was due to "hot corrosion" (sulfidation) caused by excessive $\mathrm{SO}_{2}$ and low oxygen pressure. The grain growth observed indicates that the tube-wall temperature was probably closer to $1093^{\circ} \mathrm{C}\left(2000^{\circ} \mathrm{F}\right)$ than to the $899^{\circ} \mathrm{C}\left(1650^{\circ} \mathrm{F}\right)$ nominal bed temperature intended during operation.

Corrective actions for subsequent runs in the MERC FBC are yet to be determined; however, a more uniform distribution of coal and air throughout the bed volume must be obtained to avoid the apparent hot-spots and simultaneous reduction of $\mathrm{SO}_{2}$ partial pressure. It would also be advantageous to monitor the tube-wall temperature throughout the bed volume.

\subsubsection{Exāmination of Corrosion Coupons from Wilsonville, Alabama Solvent Refined Coa.l Plant (B. C. Lecllc and R. 'l'. King)}

A set of about fifty corrosion coupons were received from the Wilsonville, Alabama Solvent Refined Coal Plant. The twelve sperimens suspended above the nominal liquid level in the dissolver tank have been metallographically examined. Mnst have a nonuniform, multiphase scale. A photograph1c summary is being prepared, and microprobe analyses to determine the nature of the scale are in progress. 


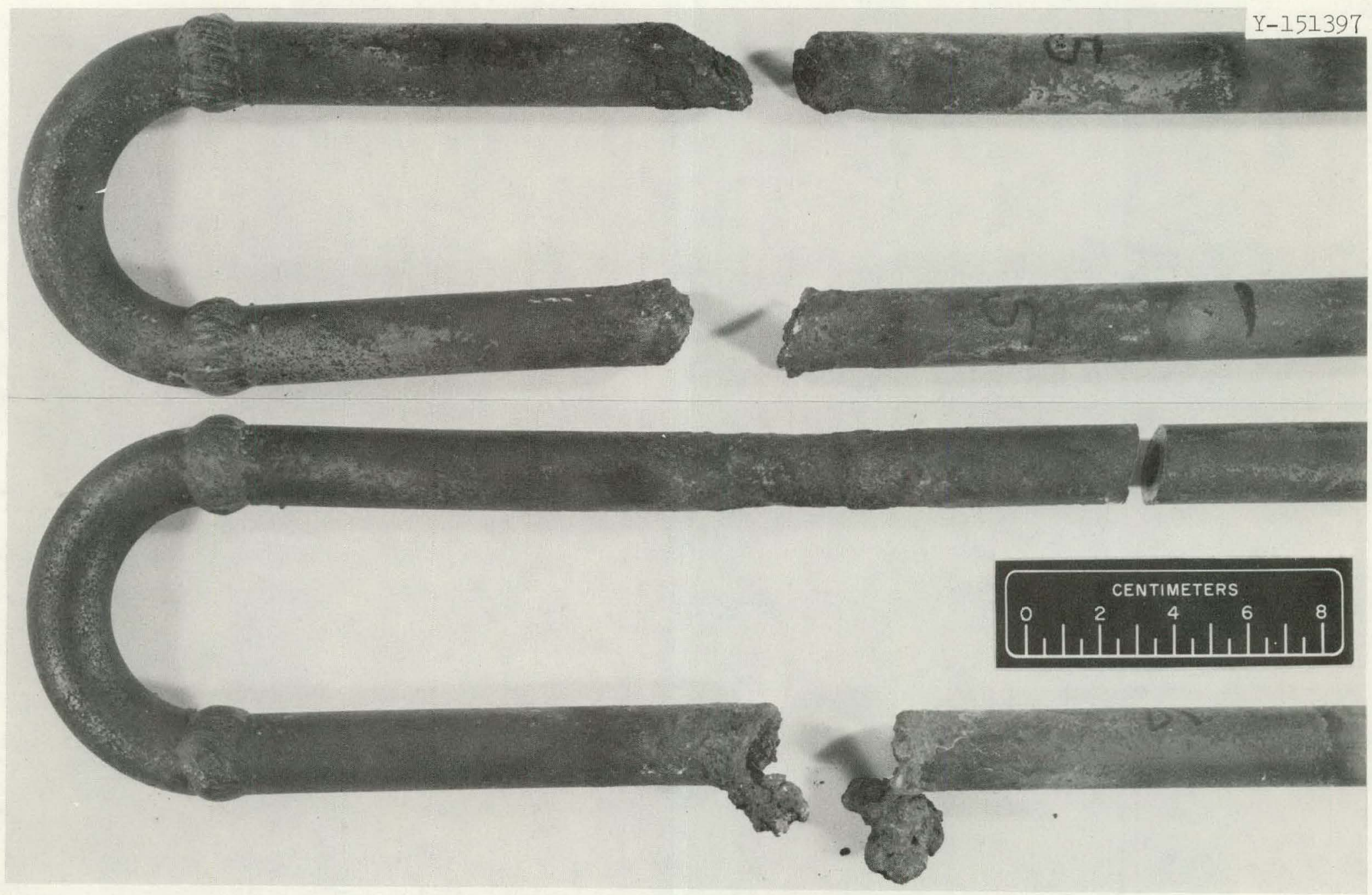

Fig. 3.1. Photograph of Failed Heat Exchanger Tubes from MERC FBC. Tubes are $1 / 2$ in. NPS, sch. 160, type 316 stainless steel. Note the corrosion on the upper half of the bottom tube. 


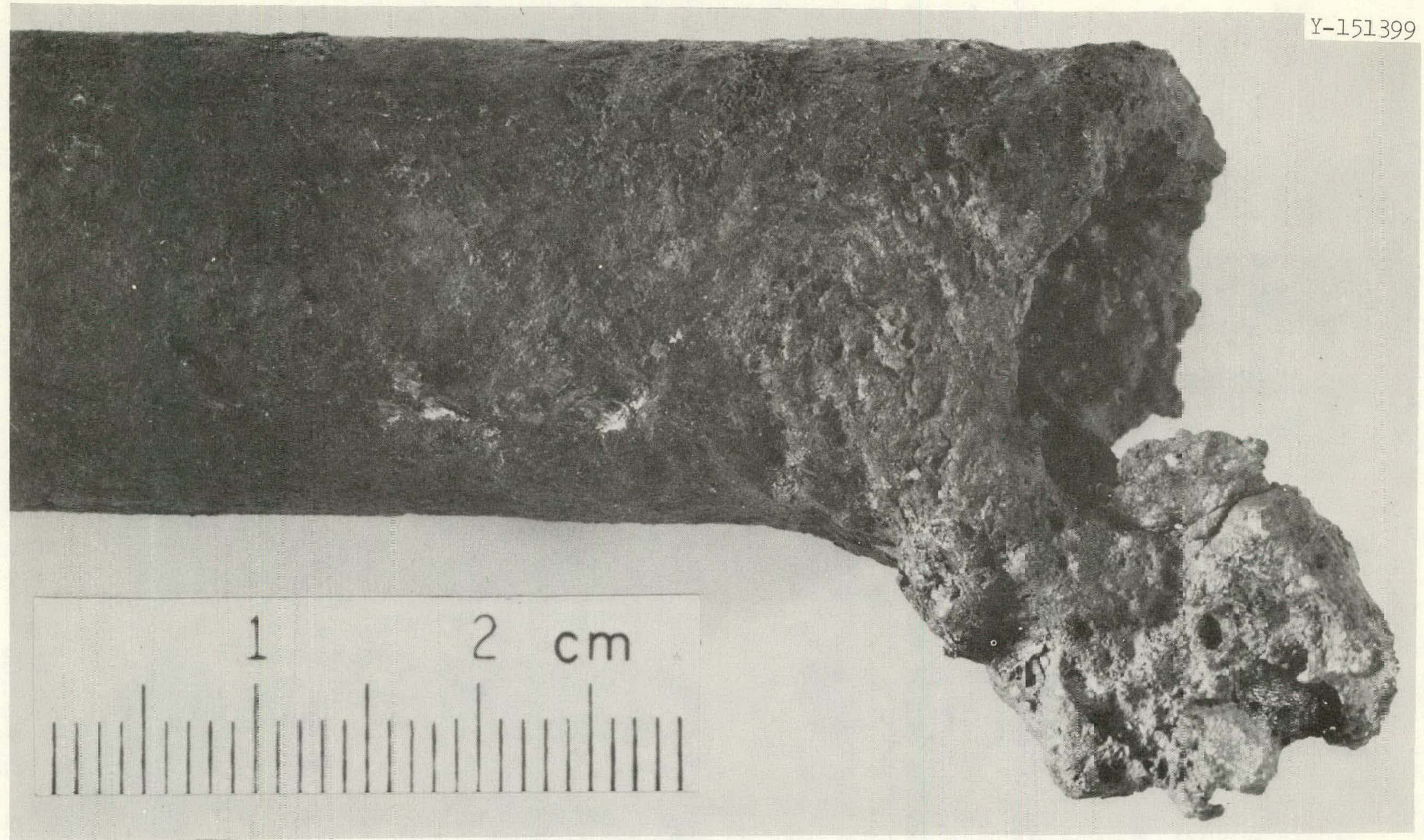

Fig. 3.2. Close-up of the Melted Portion of the Bottom Tube oz Fig. 3.1. 


\subsection{References for Section 3}

1. Fossil Energy Quarterly Progress Report, for period ending December 31, 1977 (in press).

2. Fossil Energy Quarterly Progress Report, for period ending June 30 , 1977, pp. 177-184, ORNL-5327. 


\title{
4. ALKALI METAL VAPOR TOPPING CYCLE
}

\author{
R. S. Holcomb
}

\subsection{Gas-Fired Potassium Boiler}

R. S. Holcomb, D. B. Lloyd, and R. H. Guymon

\subsubsection{Contract Objective}

Design, construction and testing of a full-scale potassium boiler tube bundle and burner module on water and then potassium to determine the performance and operating characteristics.

\subsubsection{Status Summary}

1. The secondary containment on the potassium liquid return line was replaced and operation of the potassium system was resumed.

2. Potassium plugging of the condenser argon vent line occurred. The argon vent line was modified and electric heaters and insulation were installed on the line to alleviate this problem.

3. Performance testing was initiated and about five hours of stable boiling operation was obtained at power levels up to about $3.5 \times 10^{6}$ Btu/hr.

4. During a short run at $3.9 \times 10^{6} \mathrm{Btu} / \mathrm{hr}$ the temperature at the top of the argon separator was inadvertanly allowed to reach about $600^{\circ} \mathrm{F}$. This allowed a quantity of potassium to he carried over to the potassium bubliel Lrap, and the crap was filled with liquid. After the air dampers were opened to reduce the temperature on the argon separator, the liquid in the argon vent line froze, plugged the line, and this forced a shutdown.

\subsubsection{Plans for Next Month}

The argon vent line and bubbler trap wil1 he heated and tha potaosium will be blown out of the vent lines. Performance testing will then be resumed.

\subsubsection{Technical Progress}

Work was completed on the modification and reinstallation of the secondary containment system mentioned in last month's report.

The system was refilled with potassium and operated for about an hour and a half at power levels as high as $3.5 \times 10^{6} \mathrm{Btu} / \mathrm{hr}$. The potassium was then returned to the fill and drain tank and heated to $1300^{\circ} \mathrm{F}$ to allow 
the zirconium in the tank to combine with any oxygen present in the potassium.

After the potassium had been thus purified, it was returned to the boiler and performance testing was resumed. Plugging problems in the argon vent line continued to restrict the system operation. Several modifications to the venting system were made to accommodate the potassium carryover. The entire argon venting system, from the condenser housing outlet to the potassium bubbler inlet, was trace heated and insulated to prevent the potassium from freezing and plugging the vent system.

By the end of this reporting period a monthly total of about five and a half hours of sustained, stable boiling operation had been achieved at power levels up to about 3.5 million $\mathrm{Btu} / \mathrm{hr}$.

During a short run at $3.9 \times 10^{6} \mathrm{Btu} / \mathrm{hr}$, just before the end of this period, we inadvertantly allowed the temperature at the top of the argon separator to reach $600^{\circ} \mathrm{F}$, and a quantity of potassium was carried over to the bubbler; the potassium filled the bubbler and plugged the final vent line. Preparations are in progress to heat this portion of the system after which the potassium will be blown back through the vent line into the boiler. 


\section{COAL EQUIPMENT TEST PROGRAM}

J. M. Holmes and R. E. MacPherson

Work under the Coal Equipment Test Program (CETP) is currently divided into three sections:

- Critical Equipment for Demonstration Plants

- Coal Feeder Test Program

- Survey of Industrial Capability for Coal Handling Equipment

\subsection{Critical Equipmenl for Demonstration Plants}

J. M. Holmes and L. E. Keagan

Negotiations continued with two DOF demonstration plant contractore and their subcontractors concerning non-disclosure agreements for use by TRW in their CETP study. It was erroneously reported last month that agreement had been reached with Memphis Light, Gas \& Water Division (MLGW) for the U-Gas information. Negotiations between MLGW and its subcontractors are currently in progress and are scheduled for completion by February 22, 1978. The status of the negotiations with the Illinois Coal Gasification Group (ICGG) is as follows:

ICGG - agreement completed

R. M. Parsons Co. - agreement completed

Dravo Corp. - agreed to release information in the ICGG propusal

Benfield Corp. - agreed to release information in the ICGG proposal

COGAS Development Co. - agreement reached, not yet received

Ford, Bacon \& Davis - agreement reached, not yet recelved

Allied Chemical - negotiations in progress

A presentation was made by UCC and TRW personnel on the CETP background, program plans, status and need for cooperation to MLGW and their subcontractors, Foster Wheeler Energy Corp. (FWEC) and Institute of Gas Technology on January 27, 1978 at Livingston, New Jersey. Of major concern to FWEC and MLGW was the incompatibility between their design milestones schedule and the June 1978 completion date of the TRW contract. FWEC expressed a desire to cooperate but indicated that the basic information would not be available by this date. It was agreed that technical discussions between TRW and FWEC would be started in March 1978 based upon the T'RW conceptual Ü-Gas flowsheet.

TRW is currently making contacts with the following potential test sites to obtain data on their present capabilities and availability for use by the CETP:

- Morgantown Energy Research Center

- Pittsburgh Energy Research Center

- Battelle Northwest Laboratory, Richland, Washington 
- Ames Laboratory, Ames, Iowa

- Oak Ridge National Laboratory

- Liquid Metals Test Center, Santa Susana, California

- Watts Bar Steam Plant, TVA, Tennessee

Additional sites will be identified and evaluated in the near future.

\subsection{Coal Feeder Test Program}

J. M. Holmes, B. T. Thompson, Jr., H. F. Hartman

ORNL is undertaking a program for testing coal feeders currently under development by DOE and managed by Jet Propulsion Laboratory (JPL), Pasadena, California.

Work continued on obtaining background information for the feeder systems recommended by JPL for further development. A list of detailed questions on process and test parameters was submitted to JPL for transmittal to the three feeder-developers. A preliminary estimate was made for the ORNL engineering effort required to prepare criteria for conceptual design of a pilot scale feeder test facility.

A comprehensive coal handling and feeder testing/development program, proposed for DOE by JPL, was reviewed and comments were forwarded to JPL on this program. A detailed list of proposed activities for the coal handling program was developed based upon information obtained from ORNL Coal Program personnel and outside contractors who have studied large scale coal conversion systems. Future work on the ORNL coal feeder program will depend upon the resolution of the JPL feeder test plans.

\subsection{Survey of Industrial Capability for Coal-Handling Equipment}

J. M. Holmes \& F. C. Zapp

A survey was initiated in January 1978 to determine the present capability of industry to supply equipment needed for large commercial scale coal conversion plants. A program plan is under preparation and will be presented to DOE for approval during February 1978. The survey will also determine components that are suitable for modification and/or scaleup and recommend programs for the development of components not currently available for large-scale plants. 


\section{ATMOSPHERIC FLUIDIZED BED COAL COMBUSTOR FOR COGENERATION (AFB CCC)}

R. S. Holcomb

\subsection{System Design and Assessment}

The request for proposal and the performance specifications were revised and sent to DOE-FE for final review.

Work on the application assessment study has progressed well. Analysis of typical process applications has been completed, including processes in the petroleum, chemical, paper and food industries. The compilation and review of detailed data on industrial energy use has been nearly completed. Conceptual design of CCC systems for industrial applications is more than halfway completed. It is expected that the first draft of the study report will be finished by the end of February.

The choice between Buildings 9401-1 and 9731 for the location of the CCC test system was reexamined at some length and new cost estimates were made for both locations. Progress in the development work being conducted in 9401-1 combined with some projected slippage in the CCC construction schedule has eliminated the need for preinstallation of some of the development equipment before the original equipment is relocated. This has resulted in a decrease in the estimated cost of modification of Building 9401-1 so that it will be less expensive to use than Building 9731. The lower cost, coupled with the fact that Building 9401-1 is better located for coal delivery and ash removal, has led to the decision to designate 9401-1 as the CCC location rather than 9731.

\subsection{Supplemental Studies}

Installation of the coal feed system in the fluidized bed cold flow model test facility has been nearly completed. It is planned to run trial tests involving feeding limestone into the empty bed before the end of next month.

Merallographic examination of samples from three tubes that had a total exposure time of $1500 \mathrm{hr}$ has been completed. The samples were of three materials: 310 and 316 stainless steel and Incoloy 800 . The depth of oxidation attack on all of the three materials was ahnut the same as was observed for $500 \mathrm{hr}$, indicating that the oxidation attack does not progress with time, but that the oxide layer formed early in the exposure tends to be protective. The depth of intergranular attack observed in Incoloy 800 is also the same as that seen after $500 \mathrm{hr}$, also indicating that the intergranular attack does not progress with time. Precise optical measurements of the sound metal wall thickness indicated that there was no measurable loss of wall thickness after $1500 \mathrm{hr}$ exposure. Additional information is reported in Section 3:4. 


\title{
7. ENGINEERING STUDIES AND TECHNICAL SUPPORT
}

\author{
J. R. McWherter
}

Engineering studies and technical support are provided primarily for the DOE/FE Division of Coal Conversion. The effort includes: the development of analytical tools for use in the evaluation of processes and equipment; the technical and economic evaluation and comparison of coal conversion processes and subprocesses on a uniform basis; surveys of the need for coal conversion equipment and the capability of industry to provide such equipment; and studies of the magnitude and control of coal conversion plant emissions.

\subsection{Process Modeling}

R. Salmon, 0. L. Culberson, D. M. Lister

\subsubsection{Contract Objective}

The objective is to assist DOE/FE in its plan for computer analysis and computer support for coal conversion studies. This includes assistance to Purdue and Lehigh Universities in the development of computer programs for this plan. Physical property data are being collected and computerized primarily by Purdue and will be used in support of programs prepared by both universities. Purdue's general design program will aim at material and energy balances, equipment size and costing, plant capacity, and general economics. Lehigh's dynamic simulation programs will address plant design primarily from the standpoint of process performance during transient operations, but can also be used for steady-state conditions. A single flowsheet will be selected to assess the operability and complimentary utility of both design programs.

\section{1 .2 Status Summary}

Work continued on the editing of the Purdue physical properties and material balance routines for compilation on the Fortran compiler used by the ORNL IBM $360 / 195$ system. All source modules have now been placed on the Librarian system, and the changes needed for compatibility with the IBM compiler have been made. All of the modules have now been compiled successfully in both single and double precision.

Trail runs have been made with the heat of reaction routine HTREAC. A11 of the modules required for the HTREAC routine were linked and executed successfully. The numerical results were slightly different from those obtained by Purdue, and reasons for the differences are being investigated. Additional test examples are being run. 
A meeting was held in Washington on January 25 to review the status of the project. Representatives of DOE, Purdue, Lehigh, DARCOM, and ORNL were present. It was agreed that ORNL would implement both single and double precision versions of the Purdue program in order to accommodate a greater number of potential users. Problems of documentation were discussed in relation to the training of prespective users.

Preliminary coding was: completed for the calculation of cost factors for use in the capital cost estimating module.

\subsection{Synthetic Fuels Process Research Digest}

F. M. O'Hara, Jr. and R. W. Glass

\subsubsection{Contract Objective}

The objective is to provide continuing technical assistance to DOE/FE by preparing digest reviews of current or potential subjects relating to coal conversion technology.

\subsubsection{Status Summary}

Work progressed significantly on the second volume of the Digest during this month. Final in-house editorial review was completed for the article on the Consol Synthetic Fuel Process, figures for the article were submitted for drawing, and text was submitted for composition review.

First draft typing for the article on the SRC-II process was completed and the article has been submitted for in-house editorial and technical review. The article is about twice as long as projected because it includes a description of the historical development of coal liquefaction chemistry from 1861. The historical review introduces and interrelates three of the projected review articles (CSF, SRC-II, and Fischer-Tropsch). Tt was decided (with DOE concurrence) to center the entire second issue on this theme and to defer publishing the projected article on coal gasification for medium-Btu fuel until a later issue.

Four bibliographies on the Fischer-Tropsch process, as it relates to DOE objectives and interests; were compiled from various computerized information files. 'l'he material in these bibliographies will complement the earlier research conducted on Fischer-Tropsch in preparation for the present writing.

An Award of Merit was presented to the Digest author for the article, "Conversion of Methanol to High-Octane Gasoline," which appeared in the first volume of the Digest. The award resulted from a nationwide competition of technical writing and publishing conducted by the East Tennessee Chapter of the Society of Technical Communication in preparation for the Society's international competition. 


\subsection{Survey of Industrial Coal Conversion Equipment Capabilities}

W. R. Williams, T. M. Andress, W. F. Boudreau, W. A. Bush,

W. R. Gambill, D. W. Hatcher, J. R. Horton, J. P. Meyer,

W. R. Reed, C. B. Tolliver

\subsubsection{Contract Objective}

The objective of this project is to conduct surveys of industrial equipment capabilities that will identify the present capability of industry to supply the equipment needed. The project will also determine research and development needs, including lead time requirements, for producing equipment of advanced design for the various unit operations of critical importance to the Division of Coal Conversion (CC).

\subsubsection{Status Summary}

Names of individuals to be contacted concerning pilot plant equipment operating experience and demonstration plant equipment requirements are being obtained. T. K. Lau, the DOE project manager for this survey, is presently making initial contact with the respective DOE project managers for the various pilot and demonstration plant projects. A file containing the latest information on each of eight selected pilot plants was established. Basic flow diagrams for the demonstration plant equipment review were collected. This information will be updated as additional material becomes available.

Correlations of equipment price with various parameters are being reviewed. Equipment cost files were set up for pumps and compressors via use of existing estimates for DOE coal conversion facilities.

Conceptual design reports are being studied for information on applications requiring let-down valves, expansion joints and mechanical connectors. A computer search for literature pertaining to these equipment items has been initiated. In preparation for an industry survey concerning the availability of this equipment, lists of manufacturers are being prepared.

Three of four reports on FY-1977 survey work have been submitted for editing. The fourth should go to the editors in early February.

T. K. Lau visited ORNL on January 18 and 19. During this visit, the FY-1978 work statement was finalized. Also, Lau requested that W. R. Gambill and J. P. Meyer prepare brief written descriptions of potentially promising experimental work which might be supportive of DOE/FE equipment development programs. Suggestions for experimental work are a result of the FY-1977 survey. 


\subsection{Flash Hydropyrolysis}

S. P. N. Singh

\subsubsection{Contract Objectives}

The objectives are to perform a preliminary technical and economic assessment of the Cities Service and the Schroeder-Spencer Chemical Company flash hydropyrolysis processes and to determine whether a more detailed engineering evaluation is justified.

\subsubsection{Status Summary}

The revised version of the draft final report titled Scoping Study on Two Flash Hydropyrolysis Processes was forwarded to DOE on January 4, 1970.

DOE/FE comments have been received. Copies are also being sent to: Cities Service Research and Development Company and Professor W. C. Schroeder for review and comment prior to final publication of the report.

\subsection{Hot Gas Purification Processes}

M. S. Edwards and J. P. Meyer

\subsubsection{Contract Objective}

The objcctive of this project is lu invesligate the present state-ofthe-art hot gas cleanup processes. The application of most interest is the removal of contaminants from coal-derived fuel gas prior to firing combined cycle turbines.

In this work, a survey of the available processes and processes under development for the removal at high temperature of various contaminant materials (particulate, sulfur, nitrogen, and alkali metal compounds) has been conducted. Based on the data obtained in this work, from a variety of sources, an analysis has been performed to evaluate the performance of a number of potential cleanup processes in light of the overall system needs.

\subsubsection{Status Summary}

A draft of the final report, UKNL/TM-61\%, A Survey of Processes for High Temperature - High Pressure Gas Purification, was transmitted to DOE on January 3, 1978. It includes a review of the available systems for the removal of particulates and sulfur and nitrogen compounds to levels compatible with high temperature - high pressure turbine operation. A meeting was 
held at ORNL with the DOE project manager (T. B. Simpson) on January 12 , 1978. At the meeting the conclusions of the draft report were reviewed.

Approval has been received from DOE to proceed with publication of the report.

\subsection{State-of-the-Art Review of Heat Recovery Processes \\ W. R. Gambill and W. R. Reed}

\subsubsection{Contract Objective}

The objective of this review is to survey, appraise, and catalog the processes for heat recovery which industry offers or plans to offer or may logically be expected to offer. These processes will be applicable to the recovery of heat in process streams from primary exothermic coal conversion and combustion process steps. Simple unaugmented application of conventional heat transfer equipment will not be included. The review will distinguish between presently installable technology, near term developable technology, and future prospects. Consideration will be given to possible transfer of technology from other industries.

\subsubsection{Status Summary}

Preparation of the final draft report was completed and copies were distributed for review within ORNL and DOE/FE. During our meeting with T. B. Simpson, DOE project monitor, in Oak Ridge on January 12 , he indicated that we should include whatever additional information is available on the rellabllity of cual-gasifier heat-recovery steam generators. We are : presently making this change, following which the report will be edited, retyped, and published.

\subsection{Assessment of a Moving Bed System for Cleanup of Raw Gasifier Gas \\ R. W. Glass and W. R. Gambill}

\subsubsection{Contract Objective}

The objective is to evaluate the feasibility of a proposed moving bed system for removal of sulfur and particulates from raw gasifier gas.

The assessment considers two basic hot gas treatment systems, with each system specifically addressing sulfur and particulate removal. The reference system incorporates a panel filter for dust removal and fixed bed adsorber/regenerator units. The projected system incorporates a 
moving bed filter/adsorber unit, with fluid bed regeneration of the recycled filter/adsorber media. Both systems produce high pressure steam (waste heat boiler) from the regeneration off-gases. The assessment includes simple equipment flowsheets and material balances for both systems, and comparative economics are developed.

\subsubsection{Status Summary}

A general review of the project was held on December 12 at ORNL with $\mathrm{DOE} / \mathrm{FE}$ project manager $\mathrm{Dr}$. T. Simpson. Comments on the final draft report were considered and except for the possible inclusion of supportive data on attrition (supplied by Dr. Simpson) the report is ready for final. processing.

The assessment considers two basic hot gas treatment systems, with each system specifically addressing both sulfur and particulate removal. The reference system incorporates a panel filter for dust removal. and fixed bed adsorber/regenerator units. The projected system incorporates a moving bed filter/adsorber media. Both systems produce high pressure steam (waste heat boiler) from the regeneration off-gases. The assessment. includes simple equipment flowsheets and material balances for both systems, and comparative economics are developed.

7.8 Technical/Economic Assessment of Hydrogen Production by the Steam/Molten Iron Process

R. W. Glass and L. Seglin*

\subsubsection{Contract Objective}

The objective is to determine whether there is sufficient incentive to develop the subject process for production of hydrogen from coal. The project considers specifically the comparison of the subject process (a molten-iron/steam concept) to the more conventional concepts employed in the Koppers-Totzek and Bi-Gas processes. All three processes are considered as part of an overall integrated SRC-II system. Process flowsheets, system costs, and product distributions will be described for each case and comparative economics developed. A development program for bringing the molten-iron process to the state of commercial availability will be addressed.

\subsubsection{Status Summary}

A progress review meeting was held at ORNL on December 12 with DOE/FE project manager Dr. T. Simpson. Ihe final report draft was reviewed again, and discussions to the effect of rescoping the project study were initiated

\footnotetext{
* Consultant.
} 
by Dr. Simpson. The effect of such changes are undergoing further consideration, and final processing of the report will await the outcome of these considerations.

The project considers specifically the comparison of the subject process (a molten-iron/steam concept) to the more conventional concepts employed in the Koppers-Totzek and Bi-Gas processes. All three processes are considered as part of an overall integrated.SRC-II system. Process flowsheets, system costs, and product distributions are described for each case and comparative economics are developed. A development program for bringing the molten-iron process to the state of commercial availability is discussed.

7.9 A Study of Effluent Control Technologies for Hydrocarbon and Carbon Monoxide Emissions from Coal Conversion Plants

J. Fisher and G. R. Peterson

\subsubsection{Contract Objective}

The objective of this project is to provide a technical and economic comparison of processes available for the control of gaseous hydrocarbon ( $\mathrm{HC})$ and carbon monoxide ( $\mathrm{CO}$ ) emissions. The Lurgi gasification process is considered as the reference emission source, and comparisons of control technologies consider incineration as the reference control system.

\subsubsection{Status Summary}

Technical and economic studies were completed and the results were transmitted to DOE in draft form on December 20, 1977. The results indicate that incineration in a coal-fired boiler is the least expensive of the methods considered.

Preparation of a draft final report has begun. It is expected that the draft will be ready for DOE review by the end of February 1978.

\subsection{Environmental Controls for Low-Btu Gasification}

S. P. N. Singh, M. S. Edwards, J. F. Fisher, G. R. Peterson, and R. Salmon

\subsubsection{Contract Objective}

The objective of this project is to evaluate the various environmental control processes that might be used in connection with low-Btu gasification facilities and to determine the economic tradeoffs for various processes and levels of control. 
The project is divided into two phases: Phase I consists of Tasks 1 through 4 of the work statement, and covers the preparation of a detailed work plan and the selection of gasification and environmental control processes for use in the study. Phase II consists of Tasks 6 through 8 in the work statement, and covers the collection and analysis of technical and economic data on the various environmental control processes and the preparation and analysis of flowsheets showing overall systems of environmental control processes used with various gasifiers.

\subsection{0 .2 Status Summary}

Results of Phase I of the study were presented to DOE/ESP representa tives at a meeting held on December 7, 1977. At the meeting, additional work was requested to be performed on Tasks 2 and 8 of the study. Details of the additional work requested at the meeting have been reported on in the December 1977 monthly report (q.v.). In accordance with the agreements made at the review meeting a letter was forwardcd to the project coordinator at DOE/PCSD (formerly DOE/ESP) on January 18, 1978 summarizing the results of the additional study on the project.

We are currently developing preliminary design data on the low-Btu coal gasification processes with the objective of obtaining pertinent data from the process vendors/licensors regarding the environmental control processes that may be applicable to low Btu gasification processes.

\subsubsection{Open Items}

Written approval from DOE/FE/PCSD to proceed with Phase II work (required by the project work statement) has not been rereived. Verbal approval to proceed was given at the December review meeting, and written confirmation is experter snon.

\subsection{Support of the Office of Initial Operatinns (OTO)}

B. Niemann, J. F. Fisher

H. F. Hartman, and W. R. Reed

\subsubsection{Contract Ubjectives}

The objectives of this project are: (1) to perform rapid reaction reviews and analyses of documents provided by DOE on coal conversion demonstration plant projects with appropriate follow-up as requested; (2) to conduct requested evaluations in areas which include considerations of start=up, safecy, environmental pollution, maintainability, and reliability; and (3) to develop guidelines for the preparation of safety, operation, and maintenance manuals. 


\subsection{1 .2 Status Summary}

Efforts are continuing on establishing a network of specific personnel contacts within specialty groups in the ORNL Fossil Energy Program and the UCC-ND Engineering Division.

A set of generic checklists by the main functional areas (operability, startup, reliability, maintainability, safety, and pollution control) is nearing completion. These checklists apply to any large scale coal conversion plant project and contain both general and specific items.

Work is beginning on a specific design checklist strictly applicable to the special process areas of coal gasification plants.

Preliminary flowsheets of current demonstration plant processes were prepared from available published information. They are intended to serve as a basis for identifying high risk areas related to such processes.. 


\section{PROCESS AND PROGRAM ANALYSIS}

J R. McWherter

Process and program analysis studies are being conducted for the DOE Fossil Energy Office of Program Planning and Analysis. This effort includes research studies on most of the coal conversion and utilization processes. The program objective is to provide, on a consistent basis, technical and economic evaluations of competing processes and systems for coal conversion and utilization.

\subsection{Low Btu Coal Gasification}

H. F. Hartman and J. P. Belk

\subsubsection{Contract Objectives}

The objectives of this study are to survey the low Btu coal gasification processes, select the most promising processes, and provide technical and economic information on the competing processes.

\section{1 .2 Status Summary}

Work continued on planning and implementing changes to the September 1977 draft report. Al1 DOE and ORNL comments on the draft report were reviewed and work began to revise the report based on the suggestions recelved. Comments were reviewed from the representatives of processes Lhat were described in more detail and a consistent approach was planned for changing the descriptive sections. Material in the process descriptions will be modified and updated using information provided by the reviewers. Future work will be directed toward preparing a revised draft report.

A total. of 97 low Btu gasification processes were considered in the survey. Of these, 21 were selected for detailed study. The September 1977 draft report on these studies inciudes discussions of problcm arcao, economics and process applications.

\subsection{Direct Combustion}

E. C. Fox and T. D. Anderson

\subsubsection{Contract Objectives}

The purpose of this study program is to assist DOE/FE in their effort to develop a national strategy to increase the near-term use of 
coal through direct combustion; the applications of interest in this study are the small-to-moderate industrial user and the large residential/ commercial user. The following objectives will be accomplished:

1. Identify and quantify the important factors restricting the use of coal in the sectors of interest.

2. Evaluate potential technological and institutional solutions to the problems identified in (1) above.

3. Make recommendations to DOE/FE relative to the most promising approaches to increasing the near-term use of coal.

\section{2 .2 Status Summary}

Work is in progress to evaluate the alternatives to onsite direct combustion. The physical parameters that govern the cost of pneumatic and hydraulic transportation of coal are being defined and investigated. The costs of the central steam generation system are being compiled with most of the present work centered on developing steam transportation costs.

The interim report covering the first phase of the study has been transmitted to DOE in draft form. The following is a summary of the conclusions :

Coal can be combusted in several well developed and commercially available systems. The choice of the particular device depends chiefly on the coal that is available, the cost of coal, the plant size, and cost of equipment. The tradeoff is between capital and operating costs. In general, the more expensive coal equipment is more efficient, requires less labor, and is more reliable, which results in lower operating and maintenance costs.

Advanced combustion technology is focused primarily on developing equipment that can meet environmental regulations, specifically the sulfur dioxide standards. The technologies judged to be developed sutticiently to be considered an option in the near term are atmospheric fluidized bed combustion and conventional coal furnaces with and without stack gas scrubbers.

The single most important barrier to the wide acceptance of direct coal combustion in either of the sectors of interest is the question of economics. For most installations presently burning natural gas, conversion to oil firing is an option at some modest capital cost. However, converting a boiler designed to fire natural gas to coal tiring is not a practical consideration. In general, the choices which industry has are either converting their gas-fired boilers to oil firing, or building new coal-fired units. 
The question of financing brings about particularly severe problems when considering direct coal combustion because of the intensive capital requirements. In many industrial installations, the capital requirements will rival those needed to expand existing processes. As a result, the competition for capital is very important in the eyes of industry.

Direct on-site coal combustion does not provide strong economic incentives for industry in the near term. For all of the seven regions considered (Houston, New Orleans, Chicago, Minneapolis, Los Angeles, Philadelphia and Knoxville) the large installations ( $1 \times 10^{6} \mathrm{lb} / \mathrm{hr}$ steam) appeared to be at least marginally attractive over oil. But for smaller sizes, the economy of scale and increased transportation costs for coal makes them less attractive. Houston, Texas and New Orleans, Louisiana, which are sites representative of the highly industrialized Gulf Coast, are distant from either the eastern or western coal fields. As a result, the economic advantage of coal firing for this region is constrained to the largest sizes. Burning high-sulfur coal in a fluid bed or with scrubbers at locations near the coal mines (Chicago, Knoxville, Philade1phia) appears to be somewhat attractive for even medium size users $(500,000-$ $1,000,000 \mathrm{lb} / \mathrm{hr})$. However, burning low-sulfur coals in Knnxville and Philadelphia, which are relatively close to both high- and low-sulfur mines, also looks attractive for this size range.

For sites located near western low-sulfur coal fields, the economic incentives are fairly good for large size plants but again look poor for medium size installations with capacities less than $500,000 \mathrm{lb} / \mathrm{hr}$.

For the commercial and residential sector, there are as many barriers to wide implementation as the industrial, but economics is the most important consideration. The near term, and certainly largest application of direct coal combustion as it applies to this sector is for space heat and hot water. l'he inherent low utilization of space heating equipment makes a severely capital intensive system sur.h as coal unattrartive sompared to burning oil for most regions of the country.

Regardless of the method of combustion, converting to coal will significantly increase the emissions from industrial sites that were previously burning oil or natural gas. Of the coal combustion technologieo studied, the fluidized bed concept appears to be the best for reducing the emission of $\mathrm{SU}_{2}$ and $\mathrm{NU}_{\mathrm{x}}$. However, mass burning stoker furnaces appear to be the best for limiting particulate emissions. Concern over future environmental regulations and inability to meet the offset requirements in noncompliance areas arc the most serious environmental barriers to increased coal combustion for many industrial users.

For the near term, wholesale conversion of industry from oil and gas to coal combustion does not appear to be forthcoming. The lack of substantial economic incentives, increased risk due to intensified capital requirements, and the lack of a consistent environmental policy has lead industry to postpone any energy decisions. Industrial boiler fuel taxes and Federal income tax credits will motivate some of the large steam users 
to convert. However, for the near term the small and medium size users will find the incentive too small and the risks too high.

\subsection{Advanced Power Conversion Systems}

G. Samuels and A. P. Fraas*

\subsubsection{Contract Objectives}

The objectives of this project are to review selected major advanced power conversion systems and to assess these systems on the basic R\&D status.

\subsubsection{Status Summary}

Comments received on the twelve draft reports on this project have been considered and revision of the reports is in progress.

The purpose of this study is to examine the relative advantages and disadvantages of the various advanced power conversion systems being considered by DOE. The prime emphasis is on the technological aspects of the concepts, especially experimental experience in the development of the critical components essential to the technical or economic feasibillty of the concept.

The systems included in this study are conventional steam, conventional gas turbine, combined cycle, ceramic gas turbine, water-cooled gas turbine, coal-fired gas turbine, closed-cycle gas turbine, supercritical carbon dioxide, alkali metal Rankine, fuel cells, and MHD.

Draft reports covering all of the 11 systems and an overall summary report for the project have been completed. These reports have been submitted for peer review and comments.

\subsection{In Situ Coal Gasification}

W. C. Ulrich and M. S. Edwards

\subsubsection{Contract Objective}

The objective of this program is to provide technical and economic evaluations of candidate processes for the conversion of coal in situ to fluid products presently of interest. During FY 1977, technical and economic evaluations of the linked vertical well process applied to subbituminous coal were addressed. Three alternative end product configurations were considered - electricity, SNG, and syngas. In FY 1978, an evaluation is being conducted of an in situ facility for producing gasoline from methanol via the Mobil-M process. 


\subsubsection{Status Summary}

Work on a preliminary overall flowsheet for the gasoline-via-methanol facility continued, and approximate energy requirements of various plants for a grass roots facility were determined. To meet the energy requirements, a raw gas split of about $28 \%$ to fuel gas and $72 \%$ to process feedstock was estimated. Material balance and equipment sizing calculations based on this split were initiated. After these calculations are completed, a revised energy balance will be determined and the raw gas split adjusted as necessary.

Contacts were maintained with many of the organizations involved with methanol production and the Mobil-M process. Mobil Research and Development supplied ORNL with a copy of the design package which was provided to the Badger Company and R. M. Parsons for other evaluations of the Mob11-M process. Badger provided ORNL the latest quarterly report on their ongoing evaluation of methanol from coal. Contacts were also initiated with Foster Wheeler Energy Corp. and Pullman - Kellogg Co., both Ilcensees of Imperial Chemical Industries' methanol process.

\subsubsection{Open Items}

External review of the draft evaluation report, Process Designs and Economic Evaluations for the Linked Vertical Well in Situ Coal Gasification Process (ORNL-5341), is continuing. The report represents the culmination of our FY 1977 in situ coal gasiflcation analyses studies. The report describes three conceptual plants designed for utilizing gas produced from a linked vertical well in situ coal gasification process and gives results of economic evaluations based on the concepts. Final preparation will be concluded following receipt of DOE comments.

A revised work statement, submitted to DOE/FE on December 9, 1977, is being used to guide the current effort at ORNL.

\subsection{Coal Beneficiation}

S. P. N. Singh and G. R. Peterson

\subsubsection{Contract Objective}

The objective of this study is to provide technical and economic evaluations of currently used and potential coal beneficiation processes.

\section{5 .2 Statue Summary}

Project efforts culminated in a draft final report titled Survey and Evaluation of Current and Potential Coal Beneficiation Processes (ORNL/TM-5953) which was completed in October and forwarded to DOE for review and comments. The report summarizes the technical evaluations of currently used coal beneficiation techniques as well as several novel techniques. 
A meeting will be held with DOE representatives at their earliest convenience to obtain direction on the publication of the final draft report.

\subsection{Gas Cleanup Studies}

M. S. Edwards

\subsubsection{Contract Objective}

The objective of the gas cleanup study is to collect information on the technology and economics of processes for the removal of impurities (principally hydrogen sulfide) from fuel gas streams. High- and lowtemperature cleanup processes will be reviewed.

\subsubsection{Status Summary}

Comments on the draft report ORNL/TM-6077, Selection of Candidate $\mathrm{H}_{2} \mathrm{~S}$-Removal Processes Applied to Low-Btu Coal Gas, have not yet been received from DOE. The report gives detailed process descriptions and cost data for seven methods of removing $\mathrm{H}_{2} \mathrm{~S}$ from a low-Btu coal-derived gas: MDEA, Benfield, Selexol, Sulfinol, Stretford, MERC Iron Oxide, and Molecular Sieve. Each of these processes was selected as representing a particular category of gas treating.

\subsection{HYGAS Modeling}

J. P. Meyer, G. C. Frazier, J. W. Wells, and J. P. Belk

\subsubsection{Contract Objective}

The objective of this project is to develop a computer model of the HYGAS gasifier.

\subsubsection{Status Summary}

As a first step in the development of a model of the HYGAS Pilot Plant gasifier, a computer program based on the IGT coal gasification kinetic model is being prepared using information on the IGT work presented in the ERDA report, Preparation of a Coal Conversion Systems Technical Data Book, FE 1730-21. Coding for the IGT single-bed mode1 is essentially complete, and preliminary coding is underway to link two or more beds. in series as required for modeling the HYGAS process. At this time, the single-bed program is undergoing debugging and testing. Results will be compared with those given by IGT. Thermophysical property data for the program has been obtained from the following sources: 
$>$ Reaction equilibrium constants - Estimate of Coal and Gas Properties for Gasification Design Calculations, R\&D Report No. 22, Interim Report 7, OCR, Dept. of Interior, Washington, D.C., January 1971.

$>$ Heat capacity data and heats of formation - J. M. Smith and H. C. Van Ness, Introduction to Chemical Engineering Thermodynomics, McGraw-Hill Company, New York, N.Y., 1959.

Efforts have been devoted to characterizing the devolatilization phenomena as they occur in the HYGAS reactor. A major uncertainty exists as to whether or not the devolatilization mechanism can be classified into either a rapid rate or a slow rate regime. As defined by Field et al., l rapid rate devolatilization can only be experienced by particles smaller than 100 microns in size. Since this fraction constitutes less than $20 \%$ of the feed to the HYGAS unit, it may be possible to consider the devolatilization as occurring under slow rate conditions. If so, then the work of Howard ${ }^{2}$ may be used as a limiting case upon which to subdivide product yields from different coal types. Further work is required in this area to obtain information on how product yields are affected by heating rate, temperature, residence time, and coal type.

\section{8 Liquefaction}

J. R. McWherter

\subsubsection{Contract Objective}

The objective of this project is to provide technical and economic evaluation of coal conversion liquefaction processes. Ralph M. Parsons Company is working under subcontract on the project with J. B. O'Hara as Project Manager. Major tasks included in the subcontract are: (1) a Survey of Liquefaction Processes, and (2) a Detailed.Review of High Potential Liquefaction Processes.

\subsubsection{Status Summary}

Task 1. A review is in progress of the data source book prepared by Parsons which summarizes the characteristics of 32 iiquefaction processes.

l'ask 2 . Parsons developed preliminary fixed capital investment estimates and economics for the five high potential processes selected.

Additional information was obtained on the SRC II process from the latest progress reports on the Pittsburg and Midway pilot plant at Tarnma, Washington. Additional information clarifying some of the data was obtained from the Department of Energy. Parsons is revising the SRC II yields and fixed capital investment based upon this latest information. 
As a result of additional information which became available, the fixed capital investment estimate for the H-Coal process was revised.

Preliminary block flow diagrams were prepared for the five high potential processes.

From the processes included in the survey, Parsons recommended selection of the following five processes for more detailed comparison: (1) gasoline via Mobil-M, an indirect liquefaction process followed by catalytic conversion of methanol to gasoline; (2) H-Coal, a catalytic hydroliquefaction process; (3) CSF, a donor solvent process; (4) SRC, a noncatalyticpsuedocatalytic hydroliquefaction process; and (5) Fischer-Tropsch using flame-sprayed catalytic heat exchange service, an indirect process.

The recommended selection of a donor solvent process is based on the availability of information to Parsons to properly evaluate the technology.

\subsection{High Btu Gas}

J. R. McWherter

\subsubsection{Contract Objective}

This subprogram is being analyzed under subcontract by the Scientific Design Company, Incorporated (SD) with A. S. West as Project Manager. The present work is divided into three phases as follows:

1. The objective of Phase $I$ is to provide technical and economic evaluation of competing processes, concepts and systems for the production of high Btu gas from coal.

2. The objective of Phase II is to monitor and analyze data from the HYGAS Pilot Plant.

3. 'lhe objective of Phase III is to perform a technical and economical evaluation of the Battelle Agglomerating Ash Burner Process for the production of medium Btu fuel gas, synthesis gas and hydrogen from coal.

\subsubsection{Status Summary}

Phase I. No additional work was done on this phase.

Phase II. SD engineers are monitoring Test No. 68 of the HYGAS Pilot Plant which was initiated on December 29, 1977. 
8.10 Comparative Cost Estimates of Five Coal Utilization Processes

J. R. McWherter

\subsubsection{Contract Objective}

The objective of this study is to determine consistent investment costs for four different coal utilization processes plus a conventional coal-fired power plant. The study will consider a high sulfur bituminous coal, such as an Illinois No. 6 used for a 500 MW power plant. Of the four coal conversion processes, two will consider scrubbing sulfur from the flue gases, the third will consider atmospheric fluidized bed combustion with simultaneous entrapment of sulfur by injection of lime, and the fourth will consider a coal beneficiation process coupled with flue gas scrubbing. This study is being conducted under subcontract by chem Systems, Inc., with L. H. We1ss as Profect Manager.

\subsubsection{Status Summary}

The development of input information continued for the Icarus Corporation's $C \phi \$ \mathrm{~T}^{\mathrm{R}}$ program, which is being used to estimate costs for the utilization processes. The project is nearing completion. 


\subsection{References for Section 8}

1. M. A. Field, D. W. Gill, B. B. Morgan, and P. G. W. Hawksley, "Combustion of Pulverized Coal. Part 4, Thermal Decomposition," BCURA Monthly Bulletin 31 (193-214), 1965.

2. H. H. Lowry, Editor, Chemistry of Coal Utilization, Supplementary Volume, John Wiley \& Sons, New York, N.Y., 1963, p. 346. 
9. FOSSIL ENERGY ENVITRONMENTTAL PROJECT

C. R. Boston

\subsection{Stored Solids Study}

W. J. Boegly, Jr.

No additional residue or coal samples were received during January. We are waiting for samples of Slagging Lurgi and Cogas solid residues requested from England and Scotland. Information has been relayed to ORNL that a 100-hr run was made (using char from American coals) in the Cogas Pilot plant during the latter part of December. We are attempting to determine whether any of the residue/slag is in transit to ORNL, and if so, the amount and anticipated delivery date.

Both the literature review on coal pile leachate, and the Stored Solids Quarterly Report were completed in draft form during January. Following internal review and resolution of comments it is planned to issue these documents as ORNL/TM reports.

Four 6-ft-diameter, 11-ft-deep reinforced concrete lysimeters were ordered during January. Also, a modified lysimeter was designed for the coal leaching program and will be fabricated at ORNL. This lysimeter will have wire mesh sidewalls to simulate more closely conditions in an actual coal storage pile.

\subsection{Environmental Monitoring Handbook}

S. G. Delicco

During the month of January, all of ORNL's sections of the Handbook returned from the review process. Authors responded to comments and submitted their sections to the editor. Editing of all ORNL sections should be complete by the end of the month.

On January 10, a Radian representative visited ORNL to discuss the necessary modifications to their process monitoring section. On February 6 Radian's revised process monitoring section was received. It will be thoroughly reviewed for emphasis, tone, and technical content and then submitted to the editor. The date of completion is projected to be March 31 . 


\subsection{Technical Assistance}

\subsubsection{Interaction with Demonstration Plant Contractors - S. G. DeCicco}

In response to a DOE request we reviewed the December 20, 1977, Draft Statement of Work for the Memphis Fuel Gas Demonstration Plant. The Statement of Work included a summary of the environmental monitoring program and an outline for the Environmental Report. Foster Wheeler Energy Corporation (architect/engineer) prepared the document since an environmental subcontractor had not been named. The concensus of the FEEP team was that the monitoring program was a well conceived first draft, but lacked a detailed scope of work. After an environmental subcontractor is named, a more thorough scope of work can be expected. The Environmental Report outline was basically a copy of the ICGG outline with the same shortcomings. Overall, the outline is adequate but certain areas require modification, especially the section on mitigating measures. Comments on this Statement of Work were sent to DOE on January 19.

\subsection{Carryover Activities from FY 1977}

\subsubsection{Environmental and Health Aspects of Disposal of Solid Wastes from Coal Conversion: An Information Assessment - H. M. Braunstein}

This document is receiving final in-house review and is now scheduled to go to the printer on March 15, 1978. The original target date was missed because the required in-depth review was not completed on schedule and because of higher priority assignments.

\subsubsection{Environmental Considerations for Inclusion in PON's, RFP's, and ER's: Fossil Energy Demonstration Plants - M. S. Salk}

Final revisions were completed, sign-offs by all internal reviewers were obtained, and the document was sent to DOE for final approval. It will be published as an ORNL/TM. 
10. MAGNETIC BENEFICIATION OF DRY PULVERIZED COAL

D. M. Eissenberg, E. C. Hise, and M. D. Silverman

This program was initiated during FY 1977 using Advanced Power Systems Program Development funds.

\subsection{Objective}

The objective of this project is to develop and demonstrate a novel process for coal beneficiation by magnetic separation of pyrites and ash from dry pulverized coal.

\subsection{Status Summary}

\subsubsection{Program Status}

A 189 has been submitted formally to the Division of Solid Fuels Mining and Preparation for funding for the remainder of FY 1978. Favorable action is expected by March.

\subsubsection{Separability Studies}

The data-taking phase of the comparative study of the potential of magnetic versus heavy media separation of high sulfur eastern coals has been completed and the results are being analyzed. The final tests involved a Lower Kittanning coal (Jefferson City, Pennsylvania) which contained $1.2 \%$ total sulfur, $0.45 \%$ pyrite and $15.6 \%$ ash.

A preliminary examination of the data indicate good agreement between the total magnetic fraction removed directly and the sum of the magnetic components of the float-sink fractions.

\subsubsection{Magnetic Separation Loop}

Site visits were made to the magnetic laboratory of the Chemical Engineering Department of Auburn University and to the TVA Bull Run Power. Plant to consult, to observe equipment operation, and to obtain operating data. The operating condition requirements for a direct fired pulverized coal boiler and the data and operating experience developed thus far for high gradient magnetic separation of dry pulverized coal are being compared to aid in orienting the experimental program toward the development of a set of mutually compatible operating conditions. 
10.2.4 Auburn University Subcontract

A final report of the subcontract work was not received as expected this month. A draft report is expected in February. 
11. ATMOSPHERIC FLUIDIZED BED COMBUSTION DEMONSTRATION PLANT

C. B. Smith and J. E. Jones, Jr.

\subsection{Demonstration Plant Management Support}

W. H. Fleischman, J. W. Wells, S. E. Hamblen, and H. A. Mitchell

\subsubsection{Project Status}

The date for issuing the Program Opportunity Notice has been delayed at least until the start of FY-79 in order to assess the impact of the proposed Environmental Protection Agency requirements on the esonnmic potential of AFBC utility-size plants.

\section{1 .2 Support Studies}

Technical support studies are devoted to developing proposal evaluation techniques with the recent efforts centering on improving the equipment cost data base and developing computer codes for rapid evaluation of technical data in proposals.

Computer codes for energy and mass balances, heat transfer surfacing, and steam cycle computations are being developed. Comparisons with the data in the monthly reports from the TVA/DOE demonstration plant design studies are in progress. Comparison with some GE steam cycle information shows good agreement with the steam cycle code. The steam cycle code is an existing code that may require little if any modification to be useable for this project.

\subsection{Technology Assessment}

M. Siman-Tov, H. D. Cochran, T. G. Godfrey, R. E. Kuh1man, M. E. Lackey, and G. Samuels

Technology assessment activities have resulted in a definition of the problem areas associated with the demonstration plant and assignment of a team member to be responsible for improved definition of each problem area, determination of existing and planned programs in the area and defining additional work that should be accomplished. The literature survey, AFBC library and team members past experience was used to develop the initial definition of the problem areas. Visits to AFBC operating facilities and involved organizations are being planned as an aid to further definition of the problem areas and current programs. A list of topics and questions for discussion during the visits is being prepared. 
ORNL/TM-6274

\section{INTERNAL DISTRIBUTION}

\author{
1. S. I. Auerbach \\ 2. M. Bender \\ 3. C. R. Boston \\ 4. C. H. Brown \\ 5. G. H. Burger \\ 6. J. E. Campbel1 \\ 7. D. A. Canonico \\ 8. J. A. Carter \\ 9. B. R. Clark \\ 10. H. D. Cochran, Jr. \\ 11. E. Copenhaver \\ 12. K. E. Cowser \\ 13. R. M. Davis \\ 14. D. G. Doherty \\ 15. M. S. Edwards \\ 16. D. M. Eissenberg \\ 17. J. L. Epler \\ 18. D. E. Ferguson \\ 19. L. M. Ferris \\ 20. R. C. Forrester III \\ 21. W. Fulkerson \\ 22. E. L. Fuller \\ 23. W. R. Gambill \\ 24. R. B. Gammage \\ 25. D. A. Gardiner \\ 26. C. W. Gehrs \\ 27. R. W. Glass \\ 28. T. G. Godfrey \\ 29. W. L. Greenstreet \\ 30. M. R. Guerin \\ 31. C. W. Hancher \\ 32. L. A. Harris \\ 33. S. E. Herbes \\ 34. J. R. Hightower \\ 35. R. S. Holcomb \\ 36. J. M. Holland \\ 37. J. M. Holmes \\ 38. J. K. Huffstetler \\ 39. G. R. Jasny, Y-12 \\ 40. R. L. Jolley \\ 41. J. E. Jones Jr. \\ 42. O. L. Keller \\ 43. R. T. King \\ 44. J. A. Klein \\ 45. W. R. Laing \\ 46. R. S. Livingston \\ 47. R. E. MacPherson \\ 48. A. P. Malinauskas \\ 49. G. B. Marrow \\ 50. C. J. McHargue
}

51-56. L. E. McNeese

57. J. R. McWheter

58. J. E. Mrochek

59. P. Nettesheim

60. B. Niemann

61. L. C. Oakes

62. G. E. Oswalk

63. G. R. Peterson

64-65. T. W. Pickel

66. H. Postma

67. D. E. Reichle

68. C. R. Richmond

69. B. R. Rodgers

70. M. W. Rosenthal

71. R. H. Russ

72. T. H. Row

73. W. L. Russe11

74. R. Salmon

75. G. Samuels

76. C. D. Scott

77. D. S. Shriner

78. W. D. Shults

79. S. P. N. Singh

80. C. B. Smith

81. G. P. Smith

82. I. Spiewak

83. R. L. Spore

84. J. B. Storer

85. R. A. Strehlow

86. H. E. Trammell

87. D. B. Trauger

88. W. C. Ulrich

89. P. R. Vanstrum

90. J. S. Watson

91. J. R. Weir

92. P. R. Westmoreland

93. L. V. Wilson

94. E. L. Youngblood

95. C. S. Yust

96. S. Alpert (Consultant)

97. H. Beuther (Consultant)

98. M. Semchyshen (Consultant)

99. H. W. Sternberg (Consultant)

100. C. Streed (Consultant)

101. Patent Office

102. Lab. Records-RC

103-108. Lab. Records

109-111. Central Research Library

112. Document Reference Section 
EXTERNAL DISTRIBUTION

DOE-Oak Ridge Operations

113. Research and Technical Support Division

DOE-Denver Project Office, Suite 211, 1075 S. Yukon Street, Lakewood, CO 80226

114. A. A. Hagen

DOE-FE, Washington, DC

115. W. Bakker

133. L. Kindley

116. E. K. Bastress

134. C. W. Knudsen

117. J. D. Batchelor

135. T. K. Lau

118. J. Belding

119. T. Beresovski

120. L. M. Burman

121. E. L. Burwe11

122. E. L. Clark

136. W. G. McDaniel

123. N. P. Cochran

124. R. C. Corey

125. T. Cox

126. C. W. Di Bella

127. J. Forst

128. H. Franke1

129. S. I. Freedman

130. D. Garrett

131. W. S. Harmon

132. H. Jones

137-142. C. Miller

143. M. Neuworth

144. E. S. Pierce

145. H. E. Podal1

1.46. J. L. Powel1

147. M. Reilly

148. J. Shen

149. A. P. Sikri

150. J. Smith

151. D. K. Stevens

152. W. E. Warnke

153. J. W. Watkins

154. H. L. Weisenfeld

155. D. O. Webb

156. P. R. Wieber

DOE-Environment, Washington, DC

157. N. F. Barr

158. R. M. Jimeson

159. W. E. Mott

160. R. W. Wood

161. P. Duhame1

Department of Housing and Urban Development, 451 th St., S.W., Washington, DC 20410

162. G. S. Leighton

163. J. H. Ruthenberg

University of Kentucky, Institute for Mining and Materials Research,

213 Bradley Ha11, Lexington, KY 40506

164. Theresa Wiley, Institute Librarian

165. 0. J. Hahn

166. J. K. Shau

National Science Foundation, 1800 G Street, N. W., Washington, DC 20550 167. Robert Rabin 
168. Charles B. Sedman, U.S. Environmental Protection Agency, Research Triangle Park, NC 27711

169. N. S. Boodman, Section Supervisor, U.S. Steel Corporation Applied Research Laboratory, 125 Jamison Lane, Monroeville, PA 15146

170-181. ERDA Pittsburgh Energy Research Center, U.S. Energy Research and Development Administration, Attention: Director for J. P. Barreca, 4800 Forbes Ave., Pittsburgh, PA 15213

182-187. The Director, Morgantown Energy Research Center, P.0. Box 800, Morgantown, WV 26506

188. Tetra Tech, Inc., 1911 N. Ft. Myer Drive, Suite 601, Arlington, VA 22209, Attention: Walter McGough, Jr.

189. Cameron Engineers, Attn: Gary L. Baughman, 1315 South Clarkson St., Denver, Co 80213

190. Y. A. Liu, Department of Chemical Engineering, Auburn University, Auburn, Alabama 36830

191. Steven R. Smith, Tennessee Valley Authority, 1230 CUBB-C, Chat tanooga, TN 37401

192. Manville J. Mayfield, Tennessee Valley Authority, 1320 CUBB-C, Chat tanooga, TN 37401

193. Randy M. Cole, Tennessee Valley Authority, 1320 CUBB-C, Chat tanooga, TN 37401

194. Jack L. Gregory, Project Manager, I'RW Énergy Systems, 7600 Colshire Drive, McClean, VA 22101

195. F. N. Peebles, Dean of Engineering, University of Tennessee, Knoxville, TN 37916

196. Frank P. Baranowski, Mechanical Technology Incorporated Crystal Square. 4, Suite 310, Jefferson Davis Highway, Arlington, VA 22202

197. William C. Corder, Bechtel National, Inc., Engineers-Constructors, Fifty Beale Street, Post Office Box 3965, San Francisco, CA 94119

198-224. Technical Information Center, DOE 